\title{
Legal Cultures, Legal Paradigms and Legal Doctrine: Towards a new model for Comparative law
}

\begin{abstract}
Mark Van Hoecke \& Mark Warrington
ABSTRACT

The aim of this article is to re-consider the theoretical foundations of comparative law in the light of markedly differing world legal cultures. In essence the reader is presented with the fact that there appears to be within comparative law, differing levels of the enterprise, ranging from sociological/anthropological research carried out accross significant cultural divides to comparison accross the borders of nation states who find their laws being compared against a similar cultural and paradigmatical background. The article considers aspects of legal culture and how they might be harnessed in the reconstruction of a paradigm of legal families. The article also reconsiders the importance of legal doctrine for comparative analysis, from the internal perspective of one of the four identified legal cultural families - western legal culture. In the context of the reconsideration of theoretical approaches certain concepts relating to a defintion of law need to be considered these being: law as rules, law as culture, and law as an instrument of integration. Some paradigmatical fields and elements are been distinguished which might be useful as a framework for comparative analysis and for identifying new 'legal families' replacing the traditional, but outdated, 'legal families' distinctions.
\end{abstract}

\section{TABLE OF CONTENTS}

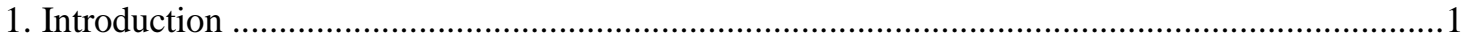

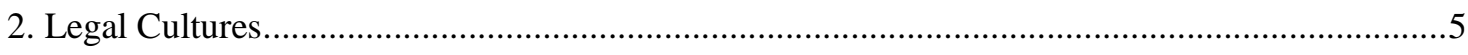

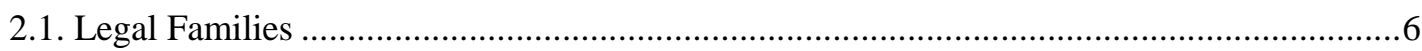

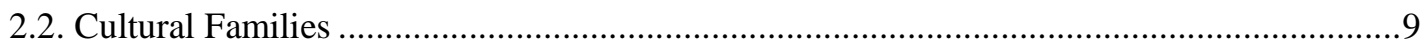

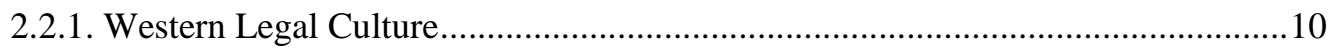

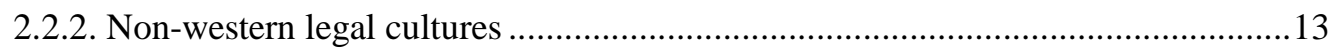

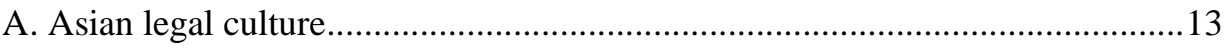

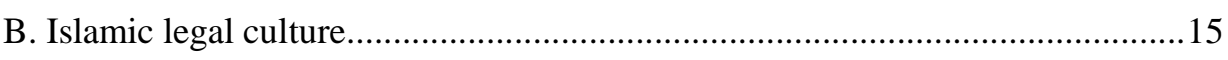

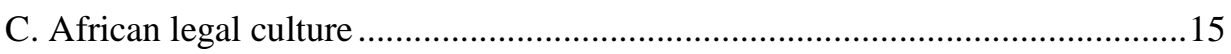

2.2.3. Intra-cultural and Cross-cultural Comparison......................................................... 16

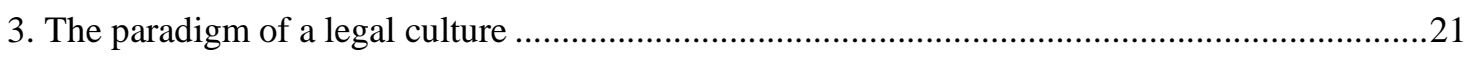

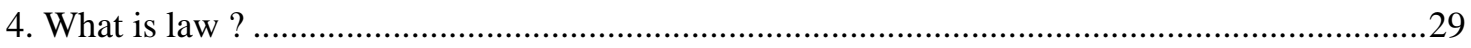

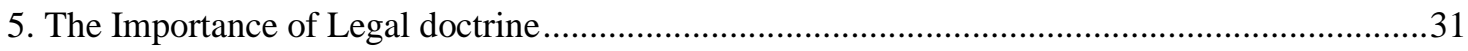

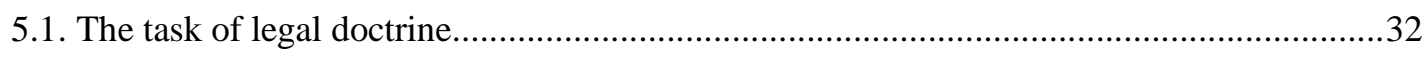

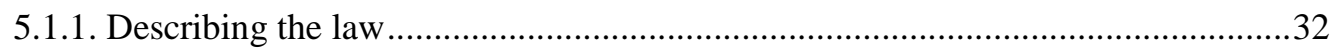

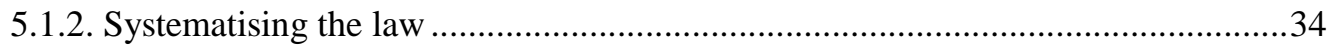

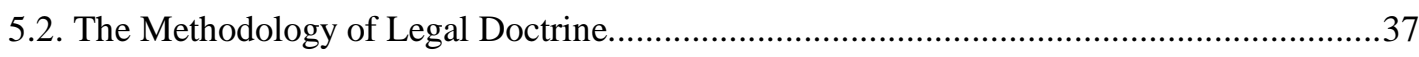

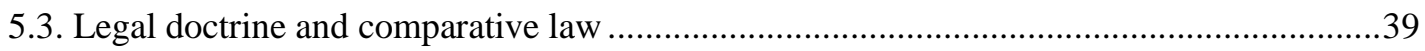

6. Towards a New Model for Distinguishing 'Legal Families' in the World...................................42 


\section{Introduction}

Over the past decade especially, many writers have emphasised the need for a broad approach to the subject of comparative law, thereby moving it beyond the law as rules approach of traditional legal doctrine. It is becoming steadily apparent that comparatists cannot limit themselves to simply comparing rules. The law as rules approach has to be placed in a much wider context. Broader investigation reveals that it is not even rules which are at the core of the comparative endeavour, it is rather the legal discourse, the way lawyers work with the law and reason about it.

The more modest approach of present comparative law limits the context to the function of the law. This functional approach has most prominently been advocated by Zweigert and Kötz. In their Introduction to Comparative Law ${ }^{1}$, in giving a balanced synthesis of previous literature and attempting to solve some of its problems and deficiencies, they offer what appears to be the most advanced approach of traditional comparative law, making an attractive synthesis of the previous literature and trying to solve some of the problems and deficiencies which stem from the subject matter. They are aware of the problems, caused by analysing foreign legal systems through one's own doctrinal concepts, and advocate an external, neutral position for comparative research, a tertium comparationis ${ }^{2}$

But when comparing legal systems and not just legal rules, Zweigert and Kötz seem to venture further (or at least become more explicit about the context which the comparatist should take into account) than their functionalist method suggests. When comparing different legal systems or groups of legal systems comparatists should "grasp their legal styles" ${ }^{3}$. This concept of style encompasses much more than the word would suggest: including history, mode of thought, institutions, legal sources, ideology. ${ }^{4}$

\footnotetext{
1 ZWEIGERT, K. \& KÖTZ, H., Introduction to Comparative Law, 2nd revised edition (transl. T.Weir), Oxford, Clarendon Press, 1987. The same approach is to be found in the most recent German edition: Einführung in die Rechtsvergleichung, Tübingen, Mohr, 1996 (see esp. at pp.33-35).

2 O.c., p.36-37.

3 O.c., p.68.

${ }^{4}$ O.c., p. 69.
} 
Along similar lines, several authors have recently advocated ${ }^{5}$ broader approaches to comparative law, and in doing so they attempt to move away from a 'law as rules' concept by using key concepts such as 'tradition', 'mentalité ${ }^{7}$, and 'culture, ${ }^{8}$.Using such an approach they essentially argue that law, and thus understanding law, involves much more than (reading) just statutory rules and judicial decisions. In other words, law cannot be understood unless it is placed in a broad historical, socio-economic, psychological, ideological context.

Such approaches to Comparative law thus seem rather different from (traditional) legal doctrine, which appears to limit itself mainly to the description, juxtaposition, and ordering of statutes and court decisions, ignoring all context of a non strictly legal nature. In fact,

5 But some already much earlier, see e.g.: DE SEIFE, R.J.A., 'Comparative Law: A Problem Solving Technique', 28 Chitty s Law Journal 1980, p.60-65, esp. p.61; GUTTERIDGE, Comparative Law, 2nd ed., Cambridge 1949, p.12; HALL, J., 'Methods of sociological research in comparative law' in: Legal Thought in the United States of America Under Contemporary Pressures, HAZARD, J.N. \& WAGNER, W.J. (eds.], Brussels, Bruylant, 1970, p.149-169; IZDEBSKI, H., 'Le rôle du droit dans les sociétés contemporaines: Essai d une approche sociologique du droit comparé', Revue internationale de droit comparé, 1968, p.563-582; KAMBA, W.J., 'Comparative Law: A Theoretical Framework', 23 International and Comparative Law Quarterly, 1974, p.485-519, esp. pp.513-515; MERRYMAN, J.H. \& CLARK D.S., Comparative Law: Western European and Latin American Legal Systems. Cases and Materials, Charlottesville, The Michie Company, 1978; NORTHROP, F.S.C., 'The Comparative Philosophy of Comparative Law' , 45 Cornell Law Quarterly, 1960, p.617-658; STONE, F.F. 'The End to be Served by Comparative Law', 25 Tulane Law Review, 1951, p. 325.

6 BELL, J., 'English Law and French Law - Not So Different ?' , Current Legal Problems, 1995, p.69.MERRYMAN, J.H., The Civil Law Tradition: an Introduction to the Legal Systems of Western Europe and Latin America, Stanford, Stanford University Press, 1969, 172 pp..

KRYGIER, M., 'Law as Tradition', 5 Law and Philosophy 1986, 237-262.

7 LEGRAND, P., 'Uniformity, Legal Traditions, and Law's Limits', Juridisk Tidskrift 1996-97, nr.2, pp.306-322, at pp.316-318; LEGRAND, P., 'Comparative Legal Studies and Commitment to Theory', The Modern Law Review 1995, pp.262-273, at pp.272-273; LEGRAND, P., 'Comparatists-at-Law and the Contrarian Challenge' (inaugural lecture at Tilburg University) (to be published).

SAMUEL, G., The Foundations of Legal Reasoning, Antwerp, Maklu, 1994, p.28.

MARKESINIS, B., The Gradual Convergence: Foreign Ideas, Foreign Influences, and English Law on the Eve of the 21st Century, Oxford, Clarendon, 1994, p.2.

$8 \quad$ The Chair for which Pierre Legrand had been appointed at the University of Tilburg in 1994 was called the chair of Comparative Legal Cultures .

Culture is a rather vague concept. Legrand defines it as the framework of intangibles within which individuals operate in a given society (LEGRAND, P., Comparative Legal Studies and Commitment to Theory, The Modern Law Review, 1995, pp.262-273, at p.263) He also refers to Alisdair MacIntyre s definition: schemata which are at one and the same time constitutive of and normative for intelligible action by myself and are also means for my interpretations of the actions of others (MACINTYRE, A., Epistemological Crises, Dramatic Narrative and the Philosophy of Science , 60 The Monist 1977, p.453). For an analysis of the (imprecision of) the concept of legal culture, on the basis of Lawrence FRIEDMANN s writings, see: COTTERRELL, R., The Concept of Legal Culture in NELKEN, D., (ed.), Comparing Legal Cultures, Aldershot, Dartmouth, 1997, pp.13-31. 
many comparative studies are remarkably close to the law as rules approach of most of traditional legal doctrine. LEGRAND thus rightly criticises such approaches:

"Crucially, it lacks a critical vocation because it betrays a fundamentally technical perspective accounting for a view of comparative legal studies as essentially utilitarian." 9

However, the following question arises wbich we attempt to deal with in the course of this article: can comparative law be fundamentally different from traditional legal doctrine ?

Describing and understanding the rules of one legal system should, in principle, be very similar to describing and understanding the rules of two or more legal systems. While the comparison, as such, is different from what is normally being done in legal doctrine, the reconstruction of legal materials compared, is essentially the same kind of work in both legal doctrine and in comparative law. If understanding law implies much more when studying a foreign legal system compared to the study of the domestic legal system, it means that there are many elements which are implicitly and unconsciously determining the way law is perceived, interpreted and applied in one's own legal system as well. If we can discover such elements, then we may well be moving towards a complete agenda for comparative law. Moreover, this is also valid the other way around: comparative law makes us aware of the elements which are influencing the law at all levels, it confronts us with our own hidden conceptual, ideological framework. Obvious things then become less obvious, once we realise that they might be completely different elsewhere. Hidden understandings are uncovered when we try to find out why foreign legal rules, approaches, and the like are different from ours.

Comparative law forces us to reflect upon our own legal system, on the 'law as rules' approach, on our own legal practice, on our own legal tradition, on our own legal education. It makes us asking what exactly determines law, what is essential to law and what is not. In order to compare legal systems we have to know what it is that makes a number of legally relevant elements to form a 'legal system'. If we want to bring together some 'similar' legal systems and distinguish them from other, 'different' ones, we have to know which kind of similarities and differences may be considered to be paradigmatical to legal systems and which ones are only casual, and of secondary importance.

9 LEGRAND, P., 'Comparatists at Law - The Contrarian Challenge', p.16, with reference to: HILL, J., 'Comparative Law, Law Reform and Legal Theory', 9 Oxford Journal of Legal Studies, 1989, p. 106107. 
Comparative law, when carried out imaginatively, compels us to consider a number of fundamental questions, some of which have already been considered in the field of legal theory for many years. Legal theory has the potential to offer some building blocks which could be of use for comparative law. Comparatists may benefit from such legal theoretical insights, which may themselves prove useful in solving some of the current problems of comparative law.

In a recent article, published under the heading 'Comparative Law and Legal Theory' John BELL shows that comparative law has lessons for legal theory ${ }^{10}$. This article in turn hopes to show that theoretical insights are essential for the development of comparative law. In this article we hope to consider what the building blocks for a theory of comparative law may be and their articulation.

\section{Legal Cultures}

John BELL defines legal culture as "a specific way in which values, practices, and concepts are integrated into the operation of legal institutions and the interpretation of legal texts" ${ }^{11}$. The concept of legal culture emphasises that law is more than just a set of rules or concepts. It is also a social practice within a legal community. It is this social practice which is determining the actual meaning of the rules and concepts, their weight, their implementation, and their role in society. However, if law is not just a set of rules or concepts, it is neither an isolated social practice. Law and legal practice are one aspect of the culture to which they belong. 'Legal cultures' are part of more general cultures. Understanding law implies a knowledge and an understanding of the social practice of its legal community. Understanding this social practice presupposes a knowledge and an understanding of the ge-neral culture of the society in which the legal community is embedded. Distinguishing legal systems means distinguishing legal communities and legal cultures. Comparing and dis-tinguishing legal families is only possible when locating these legal orders and legal cultures within the broader context of the societal culture to which they belong. If we want to distin-guish legal families, it would seem wise to have a brief

\footnotetext{
10 BELL, J., 'Comparative Law and Legal Theory', in: Prescriptive Formality and Normative Rationality in Modern Legal Systems, KRAWIETZ, W., MACCORMICK, N., \& VON WRIGHT, H. (eds.], Berlin, Duncker \& Humblot, 1995, p.19-31. 70.
} 
overview of the cultural families in the world. What follows represents a brief (albeit inevitably reductionist) attempt to outline some elements of Western and other non Western legal cultures which may contribute to the chosen approach to the subject matter.

Traditionnally, when distinguishing different legal cultures in the world two approaches prevail, depending upon the context.

\subsection{Legal Families}

In comparative law, in the second half of twentieth century three main 'legal families' were distinguished, from a western point of view: the Romano-Germanic family, the Common Law family and the 'Socialist' family. Although some different 'legal culture' was recognised in non-western societies, it could easily be upheld that most of them belonged, at least to some extent, to one of the major western legal families. Most African countries, after decoloni-zation, have, to a large extent, kept the European law imported by their colonial rulers. Their private laws are, at least formally, still ruled by the Code Napoléon or by the Common Law. All Asian countries ruled by a communist government could easily be classified under the 'socialist family'. Countries like Japan or Turkey had used the German civil code as a model for their own civil code. India, Australia, New-Zealand and other Commonwealth countries were classified under the 'Common Law' family. Actually, only the islamic countries could not really be considered to belong to one of those western legal families.

Things were both simplified and complicated around 1990, when the communist regimes in all European and in several Asian countries collapsed: the 'socialist family' suddenly disappeared. From a western perspective only two main legal families remained: the Romano-germanic one and the Common Law. ${ }^{12}$ At first sight comparative law seemed to be simplified. At a second sight, however, it was somewhat embarrassing to see how a pure political change, affecting only public law directly, could make a private law family to disappear at once. In a more critical approach, one had to ask whether it did not mean that something was wrong with the traditional legal family classification as such. After all, today nobody denies that most Central and Eastern European private law systems belong to the same Roman law tradition as the other European legal systems. Actually, Continental

\footnotetext{
Hein KÖTZ, in his foreword to the 1996 edition of his Einführung in die Rechtsvergleichung (with Konrad ZWEIGERT), enthusiastically writes that, following the collapse of the Soviet communism and the almost complete disappearance of the 'socialist legal family' in the world, this edition could be reduced by 60 pages (see at p.v).
} 
Western European legal systems are closer to them than they are to the English private law. If this common legal tradition had been interrupted for (hardly) a few decades, it is not because private law changed fundamentally, but because traditional areas of private law were taken over by public law during that period. Allthough there are important gaps in these legal systems, because of the standstill of the development of private law over more than fourty years, it is relatively easy to link up with European legal tradition. The vacuum in private law makes it even easier to adapt to recent changes in European law, than it appears to be for the EU countries themselves.

So, rather than simplifying the comparative work, these changes have challenged our traditional conceptual framework of 'legal families in the world'.

Moreover, current changes in the European Common Law countries, mainly under the influence of European law, are bringing these legal systems gradually closer to the Continental European legal systems and little by little further from their Common Law family members.

Until recently major differences in Europe between Common law and Civil law systems lie in the field of legal sources (codified law vs. judge made law) and of legal methodology (no use of travaux préparatoires).

As regards the role of the judge, even in codified legal systems ${ }^{13}$ the major role of courts is commonly accepted, and in many countries this has been the case already for a long time. Both through legal practice and legal doctrine, decisions of higher courts, and certainly of supreme courts, are considered to contain new, general rules, that have to be followed just as if they were statutory rules. Precedents are not legally binding, but they have a strong authoritative binding force. Moreover, at the European level, courts have a much stronger position than they generally have within the continental national legal systems ${ }^{14}$. The active role of the European Court of Justice and of the European Court of Human Rights is commonly accepted by legislators, by legal doctrine and by legal practice all over Europe. As these courts even have the power to condemn national States and to annul national

13 Notwithstanding the wording of, e.g., art. 5 of the Code Napoléon of 1804, still in force in several European countries, according to which it is forbidden for judges to decide cases by formulating general rules ("Il est défendu aux juges de prononcer, par voie de disposition générale et réglementaire, sur les causes qui leur sont soumises"). As recently as in 1967, in Belgium, this article has, without any change, been transferred from the Civil code to the new Code of civil procedure (where it became article 6). member of the European Communities, in 1972. 
legislation, the general image of (higher) courts on the Continent is changing, to an important extent.

On the other hand, in Ireland, England and Wales, the importance of statutory law is rapidly increasing. More and more statutes are regulating whole fields of the law, such as housing law. This is partly under the influence, or even pressure, of European directives (e.g.: consumer law), which are researched, proposed and implemented in the name of a market building strategy, part of the raison d'être of the European Union. The most basic principles of common law are still to be found in the history of court decisions, but an increasing number of intermediate principles, or rules with a general scope, are to be found in statutory law. Moreover, some of the most fundamental principles, currently in force in the European common law countries, are legislative rules, included in European treaties and enforced through European courts and administration. For the economic area - and also, but more slowly, for other important areas, such as education or criminal law - European law is governing, almost completely, the commercial law of the Member States, including, of course, the UK and Ireland. It is even enlarging the scope of commercial law to areas which traditionally were not considered to be part of it, such as sports law ${ }^{15}$. The European Convention on Human Rights, as it currently is interpreted and applied by the European Court of Human Rights, is having a direct impact on legal practice in all European countries which are members of the Council of Europe, for example as regards civil and criminal procedure. National states regularly have to adapt their legal rules and legal practice in the light of it. Of course, there are still differences between Common law and Civil law, but they are very close to a point where there will no longer be paradigmatical differences. What will be left is some difference of degree, not of a fundamental nature.

As regards statutory interpretation, similar methods are used on both sides of the channel $^{16}$, while there is a difference in one method: the use of legislative materials, to the extent that there is no English concept which covers the totality of the preparatory drafts of Acts and reports of parliamentary discussions on them, so that even the English use the French word travaux préparatoires. However, this is changing. In 1992, the House of Lords

\footnotetext{
15 European Court of Justice 15 December 1995 (Bosman case), European Court Reports, C-415/93.

16 For an interesting comparative overview, including U.K., France, Italy, Germany, Finland, Sweden and Poland as European countries and Argentina and the U.S.A. as non-European countries, see: MACCORMICK, D.N., \& SUMMERS, R.S., Interpreting statutes. A Comparative Study, Aldershot, Dartmouth, 1991, 567 pp.
} 
accepted the use of travaux préparatoires for interpreting statutes ${ }^{17}$. This decision meant more than just allowing the consultation of some category of documents which may be of use for interpreting a statute in some cases. It is a paradigmatical change, which is linked to the view on what interpretation eventually is aiming at. On the Continent, ever since the codifications, a subjective view on statutory interpretation has always prevailed. Here, interpreting a statute means finding out the (subjective) will of the legislator. In order to reconstruct as far as possible the legislator's intention when enacting the interpreted statute, travaux préparatoires are of the utmost importance. Although it not always proves possible to find in the travaux préparatoires useful information for solving the concrete interpretation problem the judge is confronted with, the use of travaux préparatoires is one of the most important methods in Continental judicial interpretation practice. In England, the approach to legislation was traditionally always a much more objective one. It was not what members of parliament or other legislators had in mind, when enacting a statute, that was important for statutory interpretation, but the 'objective meaning' of the Act, the meaning anyone would convey onto the text, without thorough historical research. When accepting the use of legislative materials ('Hansard'), the House of Lords has changed this position, or at least considerably weakened it. By this paradigmatical change the only important methodological gap between England and the Continental European legal systems has been bridged.

This is the current state of affairs in the traditional 'law as rules' approach of comparative law. The fact that the whole main 'legal families' division is now collapsing is probably only partially due to external developments. It is doubtful whether the traditional 'law as rules' approach is able to offer any sound basis for 'legal family' classifications.

\subsection{Cultural Families}

However, there has been over the last century another approach in distinguishing legal cultures in the world: the sociological or anthropological one. Here, 'law as rules' never has been at the core of the research, but rather the attitudes towards law and the imbedment of law in society and in its general culture. It is this approach which seems to be essential to start with, if one wants to develop a general framework for comparative law at world level. Inevitably, our approach will still be based on a western concept of law, but so has even been the legal education of lawyers in most non western countries ${ }^{18}$. However, by

\footnotetext{
17 House of Lords, Pepper v. Hart, 1All ER 1993, p.42. 
taking the perspective of 'law as culture' this approach should be less biased than the 'law as rules' approach of traditional comparative law.

Very generally we may distinguish four broad cultures, or cultural families, in the world: (a) African culture, (b) Asian culture, (c) Islamic culture and (d) those cultures with European roots (Europe, America, Oceania), which we can, again generally, call 'Western culture'. Certain countries are within two of these cultures, for example Russia ${ }^{19}$ or have a distinct position within one of these very broadly defined cultures, such as, e.g., India within 'Asian legal culture', but all countries may be classified generally under one (or two) of these cultural families.

Moreover, through colonialism, neo-colonialism and its currently strong world position Western culture has been, and still is, influencing other cultures, sometimes to an even dramatic extent. As regards law, fully developed legal systems are typical for Western legal culture. This makes this Western influence even more clearly seen in the development of legal culture in non-Western cultures.

Key concepts for distinguishing the Western legal culture from the other three cultural families seem to be the opposites rationalism-irrationalism and individualismcollectivism.

\subsubsection{Western Legal Culture}

In comparison with the other three legal cultures, we can distinguish two principle characteristics of western legal culture: individualism and rationalism.

By Individualism what is meant is a belief in the autonomy and total liberty of the individual in, and possibly against society. This conception is diametrically opposed to the notion of collectivism or the idea of the submission of the individual to the community. Here, the individual is considered to be unable to live or develop without being related to his, or

received from Western countries." (CHIBA, M., 'Toward a Truly International Sociology of Law through the Study of the Legal Pluralism Existing in the World' in: ARNAUD, A.-J., (ed.) Legal Culture and Everyday Life, Oñati Proceedings 1, Oñati 1989, pp.129-136, at p.131).

A long standing Asian influence made Russian (legal) culture to contain, up to now, still more characteristics of Asian (legal) culture than of the western one. For a concrete field research which shows this intermediate position of Russian legal culture, see: SANDERS, J., \& HAMILTON, V.L., 'Legal Cultures and Punishment Repertoires in Japan, Russia, and the United States', Law \& Society Review, 1992, pp.117-138. 
her society. From this premise even individual liberty is subordinated to the interest of society. Community life based on free will is contrary to a community life imposed or perceived as evident.

Rationalism means the belief in the infinite possibilities available to the human spirit to know, structure and master reality in an objective manner. This conception is opposed to irrationalism where the belief is in a preponderance of sentiment and metaphysical elements, in order to know, structure and master reality. The most opposite to rationalism are the legal systems which are directly based on religion, such as the Islamic or Hindu legal systems.

Western Individualism has been a feature of the development of western society. Ideas formulated and pursued during the time of the Roman Empire relied on distinct notions of individualism. Such notions were developed under the influence of Greek philosophy and the need to construct a liberal economy in the vast territory which was the Roman Empire. Belief in Christianity with a God, who is all powerful and personified, who creates man in his own image, also influenced this belief in Individualism. Christian doctrine also allowed a secularisation of law in the West leading to the establishment of law's autonomy. Such autonomy meant that law became the primary form of conflict resolution between individuals, reinforcing the notion of individualism in western legal thought. Even the development of forms of social law in many European countries at the end of the 19th century onwards as a reaction to marked individualism still can be viewed from an individualistic perspective ${ }^{20}$.

Rationalism is another principal characteristic of western culture. The development of rationalism was similarly aided by the secularisation of law. According to WIEACKER, it was the intellectual constructions in legal doctrine of the glossators in the late Middle-Ages, which proved the major step in a continuous process of rationalisation. ${ }^{21}$

20 Two branches of this social law were developed: Social security and Labour law. Social security, instead of being a legally organised form of social solidarity, has been developed as a system of individual social insurance covering individual risks such as illness, unemployment etc. In Labour law also, the protection of individual interests of the worker dominates, and not the collective interests of the group of workers.

WIEACKER, F., 'Grundlagen der Rechtskultur' in Tradition and Progress in Modern Legal Cultures, JÖRGENSEN, S., e.a., eds., A.R.S.P. Beiheft 23, Stuttgart, Franz Steiner Verlag, 1985, pp.176-190, at p.182. Wieacker is distinguishing three main characteristics of western legal culture: personalism, legalism and intellectualism (o.c., p.185). Actually, what he means by personalism is covered by the concept of individualism we are using, whereas legalism and intellectualism are clearly representing the characteristic we call rationalism. 
Rationalism, above all, kept its predominant role in western culture, thanks mainly to important scientific and material successes that were in a way a part of it. ${ }^{22}$

Diverse elements in Western law are cast in the image of this rational thought.

Law as the organisation of society is always a rationalisation of social relationships. All organisation is, by definition, essentially rational, if it really wants to organise. This most clearly appears in the law, because it implies an advanced organisation, which situates itself at two different levels: at a first level the rules of behaviour, and at the second the procedures for the elaboration, the change and the abolition of rules, the procedures to resolve conflicts, and the creation of institutions to ensure that such procedures are complied with. The less rationalist character of the non-western cultures makes law playing a less important role in society than it does in the West. Furthermore, law in the West was approached in a rationalistic manner. DEKKERS ${ }^{23}$ has shown that law, for Europeans, is above all a system, a form of logic, a geometry ${ }^{24}$, a coherent assembly where everything can be reduced to principles, to notions and to categories. It is also a form of equilibrium that Europeans are currently aspiring to when reflecting upon the challenges that lie ahead for those interested in the attainment of a unification of private laws in Europe.

The vision of man in our Western positive law is that of the rational man, the 'pater familias'. This rational model has been emphasised over the years in case law. So, for example, in France and Belgium, in the case of error (erreur) in a contract, there is only the

22 New belief in the infinite possibilities of the human spirit to experience reality, to master and organise it, originally manifested in the Renaissance, then in the French philosophy of the 18th century, and also to some extent in German idealist philosophy (HEGEL).

The rapid increase of scientific, technical and industrial development in the following centuries, is both an application and a result of this belief. The success of science, technology and industry has, in an inverse way, increased the belief in the value of the human mind, which in turn has also had an equal influence on science. This was not only in the positive sciences, but also in the human sciences as it resulted in the development of new disciplines such as econometrics and formal logic. As a reaction to all this, different forms of ideas came into being in which irrational elements played a large role, for example in phenomenology and hermeneutics, but they had only a limited influence on Western culture.

23 DEKKERS, R., 'Meetkunde en verzoening', Rechtskundig Weekblad 1966-67, p.129.

24 The Japanese writer NODA characterises western law 'The law of the geometric mind' and the opposite of the Japanese 'Law of the subtle mind' (NODA, Y., 'The Far Eastern Conception of Law', 2 International Encyclopedia of Comparative Law, 1971 p120). See also: KIM, Ch., and LAWSON, C.M., 'The Law of the Subtle Mind: The Traditional Japanese Conception of Law', 28 International and Comparative Law Quarterly, 1979, pp.491-513. 
acceptance of a 'rational' error, which means a mistake that a reasonable person would commit, which serves to fully invalidate the contract; or also in the application of article 1382 of the Code Napoléon, the judges have decided that a person is at fault, when he knew, or was presumed to know that his act could cause some harm to a third party. What people actually had in mind is irrelevant, the presumed behaviour of a rational person is used as a model and as a normative measure for judging people's concrete behaviour. This liability, founded on the basis of a normative presumption of knowledge is also familiar to the common law, where it is described as constructive notice ${ }^{25}$

The maxim ius vigilantibus scriptum est (law is written for those who are vigilant) abounds with the same rational sense, and more precisely in the procedure: where he who is summoned to appear in court and does not appear is almost automatically condemned; he who lets expire a delay, during which he could have introduced recourse against a judgment, irredeemably loses all rights, and is not allowed to bring his case before court again, even if he could prove in a convincing fashion that he unjustly lost his case.

For an example, where this concept is applied, see: Barclays Bank plc. v. O Brien, 4 All ER, 1993, 417, at 424a and b). 
Rationalism also made an impression on western legal theory and legal philosophy. Theories, such as KELSEN's, are an extreme realisation of that rational model. ${ }^{26}$ The same view also applies for formal logic and artificial intelligence as applied to law. Along the same line, the frequent limitation of the notion of law to law stemming from the state is an expression of faith in the primordial role of reason in the elaboration and development of legal systems.

\subsubsection{Non-western legal cultures}

\section{A. Asian legal culture}

In contrast, when one comes to consider non western legal cultures, Asian legal culture appears to be neither individualistic, nor rationalist. The Asian collectivist approach, seen most prominently in China, but also in $\mathrm{Japan}^{27}$, was determined principally under the influence of the Confucian theory of the natural order of reality. According to this traditional oriental thought every person has a duty to respect the natural order of things at the risk of perturbating that order ${ }^{28}$ Individualist rights are considered to be contrary to that natural order. The individual has no rights but only duties towards the others and towards society.

26 Which explains why the Kelsenian theories are hardly known in most Asian legal cultures: from a non rationalist point of view such theories are not only uninteresting, they can not, or at least not really, be understood (KAUFMANN, A., 'Vergleichende Rechtsphilosophie - am Beispiel der klassischen chinesischen und der klassischen abendländischen Rechtskultur' in Festschrift für Werner Lorenz, zum siebzigsten Geburtstag, PFISTER, B. \& WILL, M.R., eds., Tübingen, J.C.B.Mohr, 1991, pp.635-648, at p. 642: Die Reine Rechtslehre Kelsens ist ihnen weitgehend unzugänglich.).

${ }^{27}$ Kung Fu-Tzu, better known in the West as Confucius, lived in China from 551 till 479 before Christ. Confucianism was imported in Japan and imposed on its people under the reign of the Tokogawa dynasty (1600-1867). This religion partly mixed up with existing religions: Buddhism and Shinto, a pantheist religion of Japanese origin and strongly oriented towards nature.

In China, there was some influence from the movement, called Legalism, which was more emphasising the importance of rules, but had only a limited influence (see for a historical overview: MACCORMACK, G.D. 'Law and Punishment: the Western and the Traditional Chinese Legal Mind', in: MACCORMICK, N. \& BIRKS, P. (eds.), The Legal Mind, Oxford, 1986, pp. 235-251). See, on the influence of Buddhism on the Chinese legal culture: LEE, L.T., \& LAI, W.W., 'The Chinese Conceptions of Law: Confucian, Legalist and Buddhist', 29 The Hastings Law Journal, 1978, pp. 1307-1329.

${ }^{28}$ ESCARRA gives the following examples: Wearing warm clothes in summer or light clothes in winter could bring cold temperatures in summer and warm temperatures in winter. Executions can better be organised in autumn than in spring, because this fits better with the biological cycle (ESCARRA, J., 'La conception chinoise du droit', Archives de Philosophie du Droit 1935, 1/2, pp.11-13). See also: KIM, Ch. \& LAWSON, C.M., 'The Law of the Subtle Mind: The Traditional Japanese Conception of Law', 28 International and Comparative Law Quarterly, 1979, pp.493-494. 
Individualist rights are considered to be contrary to that natural order. The individual has no rights but only duties towards the others and towards society. When using his individual rights, the individual, wrongly, opposes himself to the society. By claiming his rights he is damaging society with his combative attitude. Therefore, conflicts are preferably not brought before the court, but solved through reconciliation ${ }^{29}$. If there is a trial, than one has to make reciprocal concessions, so that the trial can, eventually, be terminated amicably. ${ }^{30}$

In short, we may conclude that Asian legal culture, when interpreted from an (overtly) Western point of view, can be represented to a certain extent as being irrational, because of the important role of morals, of religion and of the Confucianist conception of the natural order of things. Oriental people likewise may well consider the western people to be much too rational: as caught in their own mind and in their rational concepts, they have lost all contact with the universe which is surrounding them, and they have lost the consciousness of their place in this universe.

Moreover, Asian legal culture can be perceived as being collectivist. This appears from the absence of the concept of individual rights and in the subordination of the individual to the community. Belonging to a community (company, university, sportsclub, and the like) is more important than the individual position and the individual rights ${ }^{31}$ The collective responsibility for faults and crimes provides an example of the implementation of this conception.

\section{B. Islamic legal culture}

29 The Japanese do not bring an action easily. They do so only after having tried all other methods of dispute resolution without success. (TANIGUCHI, Y., 'Between Verhandlungsmaxime and Adversary System - in Search for Place of Japanese Civil Procedure', in GOTTWALD, P. \& PRÜTTING, H. (eds.), Festschrift für Karl Heinz Schwab zum 70. Geburtstag, München, C.H.Beck, 1990, p. 496). In fact, the highest ideal of chün-tze (gentleman) is to show oneself capable of exact proportions and moderation in all circumstances. Compromise or yielding with propriety is always far more important in China than invoking personal rights and privileges. (LEE, L.T., \& LAI, W.W., o.c., p.1310). See on the weak position of the judiciary in Japan, and the importance of reconciliation: OKI, M., 'Schlichtung als Institution des Rechts. Ein Vergleich von europäischem und japanischem Rechtsdenken', 16 Rechtstheorie, 1985, pp. 151-162.

30 In traditional Korea a yangban (member of the ruling class), who was in mourning (which often lasted for a period of three years) was punished if he came personally to the court to institute a lawsuit, and his suit would not even be received (see: CHOI, Dai-Kwan, 'Western Law in a Traditional Society Korea', 8 The Korean Journal of Comparative Law, 1980, pp. 177-202, at pp. 181-182).

31 LLOMPART, J., 'Japanisches und Europäisches Rechtsdenken' , 16 Rechtstheorie, 1985, pp.131-149, at p. 145 
In Islamic legal culture there is no division between law, morals and religion. All law is based on, and deducted from the Koran, despite legal doctrine in practice being generally considered a source of law, beside and sometimes even against the litteral wording of the Koran. ${ }^{32}$ In this legal culture, moral principles have more weight than rational, systematic legal constructions.There is a reluctance towards the promulgation of acts with a general scope. The law offers rather a concrete solution for a concrete problem, in order to respect the infinite variety of social life. Legislation is only of secondary importance as a source of law. The Koran and customary law are much more important. There is more emphasis on the aim and scope of legal norms and on general legal concepts. The individual justice of the Qadi, in which equity has more weight than a strict application of the law, is essential to the islamic legal culture. Personal ties and someone's position in a social network deeply affect the course and content of judicial decision making. ${ }^{33}$ This may entail that someone's stronger position in his community gives more weight to his testimony compared to another person with a lower position. ${ }^{34}$ One could say that, because of this social definition of the individual person, islamic legal culture is less individualistic than the Western one. The individual justice of the Qadi, in which equity has more weight than a strict application of the law, is essential to the islamic legal culture. The emphasis on religion, morals and individual justice gives it also a less rationalistic basis.

\section{African legal culture}

The Western conception of the law as a weapon available for the individual against the others and against society, does not fit well with African culture, where the law is rather a means of protection within, and thanks to society. Traditional African legal thinking is not individualistic. $^{35}$

The way a trial is organised concerns the whole community, both as regards its content and its form. When someone is summoned before court by a person alien to the community

\footnotetext{
32 See: MIAILLE, M., Introduction critique q l étude du droit, Paris, Maspéro, 1976, pp.292 et seq

33 ROSEN, L., 'Equity and Discretion in a Modern Islamic Legal System', 15 Law \& Society Review, 1980-81, pp. 217-245, at p. 423. would be the fate of the individual in Africa, left to his own devices, without the support of the applied sciences ? At the risk of dying, he has to be member of a group, his family, his tribe, in order to defend himself against nature.” (DEKKERS, R., Discours Rectoraux, 1970, p.19)
} 
(family, clan, tribe, or the whole society), a reaction of defense and protection will ensue in this community, protecting he who is being attacked. In each trial there is a large audience. Rituals and palavers play an important role. Arbitration and mutual concessions are, as in Asian legal culture, more important than obtaining one's formal 'rights, ${ }^{36}$.

In Africa law is not separated from religion and morals. The pressure of religion and morals is at least as strong as the coercion of the law, notwithstanding the absence of sanctions. ${ }^{37}$ Not following the rules of a community indeed means placing oneself outside this community, which may lead to exclusion.

African legal culture appears as neither individualistic, nor rationalist. Law is not conceived as a rational system of strict rules, but rather as a means of social control in order to keep or to restore peace within a community. The solution in a concrete case will rather be guided by this general function of the law than by the strict rule as such. There is no room in an African society for the application of the maxim 'summum ius, summa iniuria'. 38

\subsubsection{Intra-cultural and Cross-cultural Comparison}

There appears to be a basic difference between these four legal cultures as regards the concept of law, the role of law in society and the way conflicts could and should be handled. In essence, these differences are so fundamantal that there is not so much to be gained by undertaking a superficial comparison by merely comparing legal rules, legal institutions, or even whole branches of legal systems belonging to the different cultural families. As Alan WATSON remarks: "except where the systems are closely related, the differences in legal values may be so extreme as to render virtually meaningless the discovery that systems have the same or a different rule". ${ }^{39}$

36 "Disputes arising, often, have to be solved by some form of arbitration. The winner-take-all phenomenon gives way in Africa to a sort of give-a-little-get-a-little phenomenon;" (OJWANG, J.B., 'European Law in Africa:Wherefore ?' in: JÖRGENSEN, S., e.a., eds., Tradition and Progress in Modern Legal Cultures, Stuttgart, Franz Steiner Verlag, 1985, pp.141-147, at p. 142).

To violate the law of the land duly enacted or 'consecrated' is to incur human and supernatural disfavour. Ill fortune, sickness or death could be the result of an unlawful act. All these traditional African views and beliefs make enforcement of a law all the more unnecessary" (OKAFOR, F.U., 'Legal Positivism and the African Legal Tradition', International Philosophical Quarterly, 1984, pp.157-164, at p.161).

VANDERLINDEN, J., 'Aspects de la règle de droit dans 1 Afrique traditionelle', in PERELMAN, Ch. (ed.), La règle de droit, Brussels, Bruylant, 1971, p.141. See also: OJWANG, J.B., o.c., 1.c., where he states that African law is marked by an exceptional appearance of informality, as compared, for instance, with most European legal systems . 
Comparing, of course, is possible, but it takes place at a different level than when for example Japanese and Korean law, or French and German law are compared. Comparison accross these four main legal cultural families becomes comparative law which draws heavily from a legal sociological or anthropological perspective, because every single legal rule, legal deci-sion or other legal practice may only be understood within the framework of a different world view and a fundamentally different conception of the law and its role in society. $^{40}$

F.S.C.NORTHROP was aware of this problem when he wrote, in 1960:

"It shows that in introducing foreign legal and political norms into any society, those norms will become effective and take root only if they incorporate also a part at least of the norms and philosophy of the native society" and "this means that the present practice of imposing purely Western secular legal and political systems on African, Middle Eastern and Asian societies, without incorporating into those systems at least some basic factors in the traditional philosophy of the living law of the native people, is likely to end in failure." 41

There is therefore an obvious all-important limitation to the influence of Western culture. Comparative law, when viewed in its narrowest sense appears only to be feasible (in terms of the aims and objectives it can pursue) within one and the same cultural family sharing a basic common conception of law.

At least some comparatists, such as KAMBA, appear to be aware of the categorical differences when making the distinction between intra-cultural and cross-cultural comparison. KAMBA defines intra-cultural comparison as "the comparison of legal systems rooted in similar cultural traditions and operating in similar socio-economic conditions" ${ }^{42}$. He emphasises that:

"The technique employed must necessarily vary to a considerable extent according to the degree of disparity or similarity in the socio-cultural foundations of the legal orders being compared." 43. KAMBA, however, seems to think that we are faced with a gradual difference only; he appears unaware of its fundamental, categorical nature. This leads obviously to a complete

Press, 1974, p.5.

In order to avoid misunderstandings, it should be emphasised that the use of the concept legal anthropology has nothing to do with some western ethnocentricity. It simply points to the fact that a broad sociological comparison has to be the first step in any such comparison, and that societies, traditions, world views have to be compared and not legal rules, concepts, institutions, isolated from this broad anthropological context.

NORTHROP, F.S.C., 'The Comparative Philosophy of Comparative Law', 45 Cornell Law Quarterly, 1960, pp.617-658, at pp.657-658.

KAMBA, W.J., 'Comparative Law: A Theoretical Framework', 23 Int.Comp.L.Q., 1974, p.511.

O.c., 1.c. 
methodological confusion:

"An important result of this is that a comparative lawyer must, to a considerable degree rely upon his individual judgment in deciding how to go about the comparison. ... However, it is important to recognise that it is not possible, nor would it be prudent to attempt to prescribe specific comparative procedures to be followed." ${ }^{, 4}$.

However, it indeed is possible to prescribe specific comparative procedures to be followed. Firstly one must consider to what extent such comments apply to the four identified general legal cultural families in the world. When one is aware of the previously outlined basic cultural differences between legal orders belonging to different cultural families, then it is obvious that a sociological or anthropological perspective is most appropriate. This means that any comparison has to start from the main cultural differences when trying to understand any legal rule, legal institution or legal practice. More critically within western culture, for those interested in comparison of the laws, such as those of EU member states, the analysis should focus on to what extent the comparison of legal systems which are indeed rooted in similar cultural traditions and operating in similar socio-economic conditions is possible.

Most importantly the difference between the written rules and legal practice should be studied. Very often non Western countries have 'imported', or kept after colonisation, European codes, concepts, institutions, and rules. While the wording of the statutory law may be still identical, and even if, at first sight, court decisions seem to be very similar to those of their European counterparts, the 'legal reality' may be very, or even completely, different ${ }^{45}$. Be it only by the way judges look at those rules, read them and interpret them in their own world view, by the way citizens look at the statutory law and at court decisions and the meaning they confer upon them. Moreover, the role of (statutory) law in society may be much weaker than it is in the West. Custom might play a more decisive role than statutory law. Social rules might effectively prohibit people in practice from making a legal claim, or even using a court decision which accepted such a claim.

Therefore it does not make any sense to look at 'law' in a legal order, that belongs to another cultural family, if this takes place from the point of view, and within the framework,

$44 \quad$ O.c., l.c.

45 E.g., in Congo many Belgian statutes and codes have been kept after the independence in 1960. Even today courts, including the supreme court (Cour de cassation) are constantly referring to Belgian court decision and Belgian legal doctrine when deciding cases. However, this does not mean that legal reality or everyday legal and social practice would be identical, or even very similar to Belgian legal daily life .. 
of one's own (legal) culture. This cannot but generate a biased view of 'legal reality'. It carries the risk of implying that there are many more similarities than there actually are. One of the clearest examples is offered by the differences in interpretations amongst the different main cultural areas as regards the international treaties on human rights over the last decades. Individual freedom had and still has a rather different meaning in China, and even in Russia, compared to the Western view, not just because of a communist ideology currently or formerly imposed by the rulers in those countries, but because of a more basic, culturally embedded ideology which starts from a very different, collectivist world view. ${ }^{46}$

Becoming aware of some of these fundamental cultural differences goes against the nineteenth century belief - still alive in twentieth century be it in different forms - in the possibility of finding some kind of basic set of legal concepts, legal rules and legal institutions that would be common to all legal systems in the world.

The aim of comparative law as a worldwide legal dicipline was advocated in the early years of the development of comparative law as a discipline in its own right. Raymond SALEILLES maintained that comparative law is a science whose object is the discovery of concepts and principles common to all 'civilised' systems of law, that is to say, universal concepts and principles which constitute what he called droit idéal relatif ${ }^{47}$.

This limitation to the 'civilised' world, as used at the end of the nineteenth and the early twentieth century by Western writers, may also be conceived as that which belongs to Western legal culture. On one hand it admittedly demonstrates a culturally biased approach, but, on the other hand, it implicitly recognizes that comparative law, when looking for similarities, with a view to legal transplants, or enhancing one's understanding of one's own legal system, or even employed in the process of moves towards unification or harmonisation, only really makes 'sense' when limited to legal systems belonging to the same cultural family. From the above sketch of the problems of cultural gaps between (legal)

\footnotetext{
46 For a criticism of the Western character of the concept of human rights from an Indian point of view, see: PANIKKAR, R., 'Is the Notion of Human Rights a Western Concept ?', 120 Diogenes, 1982, pp.75-102. documents du Congrès international de droit comparé (Paris 1900), 2 vol., Paris, 1905-1907, vol.1, p.173. See also: DAVID, R., Le droit comparé. Droits d'hier, droits de demain, Paris, Economica, 1982, p.12; CONSTANTINESCO, L.-J., Traité de droit comparé, vol.1, Introduction au droit comparé, Paris, Librairie Générale de Droit et de Jurisprudence, 1972, p.135.
} 
cultural families it should be clear that a belief in the possibility of finding some kind of 'droit idéal relatif' or 'empirical natural law' appears at present to be rather naive and never will be able to achieve any concrete result. Moreover, such observations also serve to weaken attempts to make 'world encyclopedias of law', describing within one and the same (western) framework the law in countries all over the world. One may ask how it is possible to make an international overview of 'contract law', when some problems happen to be solved under contract law in some countries, but under tort law in other ones? How is it possible to describe the concrete interpretation and adjudication of the western concept of human rights in legal orders all over the world, when one is not aware of the fundamentally different approach to these rights in the various different legal cultures $?^{48}$ It does not make much sense to simply compare the technical rules within the realm of divorce between, e.g., a European and an Islamic legal system, if one is not aware of the fact that the same problem can be solved in the one country by marrying a second wife, without needing to divorce from the first one, or that the man can simply repudiate his wife, with consequences which are comparable to a divorce in the other country. It is even more problematic to make a crosscultural comparison of legal rules, when there is, in one of the compared legal cultures, a very strong social pressure not to use these rules for solving a conflict. Mitsukuni YASAKI gives the example of a trial in Japan between 1977 and 1983:

"One day, A asked a neighbor B to take care of A's kid for a while. While A went out, A's kid unfortunately fell into a pond and died. A brought a suit against B for damage for B's negligence. The district court decided for A. B appealed to the higher court. Soon after the case appeared in many newspapers, resulting in considerable public outcry. A, heavily troubled by condemnations through telephone, letters (Why did you make such a suit against your neighbor?), withdrew A's own claim. B appealed to the court, and was attacked by the people in the same way, for the same reason (Why?).",49

The trial stopped here and the district court decision never was used by A. The author uses this example to show how under the westernised surface of a modern legal system, traditional ways of life are still very influential.

Of course, (legal) cultures are constantly influencing each other. With the current large scale of economic exchanges, within one world market, together with the increasingly rapid means of transport, the proliferation of means of communication, and the role of the mass

48 For a criticism of the possibility of universal rights in a culturally divided world, see: BELVISI, F., 'Rights, World-Society and the Crisis of Legal Universalism', Ratio Juris, 1996, pp.60-71. Verlag, 1985, pp.191-195, at p. 191. 
media in offering an insight into foreign cultures, we may witness a slow change in most cultures towards some new common basic culture at a world level. But, for the time being such differences which we have briefly attempted to elaborate are still too important to be overlooked.

\section{The paradigm of a legal culture}

How may we grasp a 'legal culture' ? What makes a 'legal culture' different from another one ? It is easy to agree that law is more than just statutory rules and court decisions. But how do we determine, describe and compare the specific way in which values, practices, and concepts are integrated into the operation of legal institutions and the interpretation of legal texts ${ }^{50}$ ? This would involve a lot of sociological and cognitive research, undertaken with a sound knowledge of the legal system. However, in as far as we do not have at our disposal the results of such a research, at least some legal theoretical research may be able to offer us some elements, that may prove useful in analysing such legal cultures, and which could be used as a tool for comparative research.

In the philosophy of science, Thomas KUHN developed the concept of 'paradigm', which refers, amongst others, to the hard core of scientific theories ${ }^{51}$. It is the common framework within which theories are developed and scientific discussions are pursued. It implies a common scientific language, a common set of concepts, and a common basic world view. If one does not accept the commonly used concepts and/or the commonly accepted ideology, it is no longer possible to develop theories within that science as it has been traditionnally conceived. Sometimes this deviant scientific behaviour attains a notable measure of success. This can be perceived as being the start of a 'scientific revolution', such as, e.g., the Copernican revolution, when it got accepted that the sun, and not the earth, is the centre of our solar system. ${ }^{52}$

Lawyers also have their 'paradigm, ${ }^{53}$ : a hard core of shared understandings, of basic

\footnotetext{
50 Which is the definition of 'legal culture' as worded by John Bell and quoted above.

$51 \quad$ KUHN, T.S., The Structure of Scientific Revolutions, Chicago, University of Chicago Press, 1970.

52 Note that the Copernican theory is already incorporated in our language, as we talk of a 'solar' system rather than of a 'planetary' system, and we do not use at all the word 'earth system'. 
theories and concepts, a common language, a common methodology. Or, to put it differently: a common legal culture within some legal community. Such a common legal culture includes shared understandings on, at least, the following points:

(a) A concept of law. What is law ? How is its relation to other social norms ?

(b) A theory of valid legal sources. Who has the power to create law, and under what conditions ? Which is the hierarchy of the legal sources ? How, and by whom are problems of collision between legal sources solved? What is the respective role of the various legal professions ? Are non-legal texts or decisions, such as religious ones, direct sources of law?

(c) A methodology of law, both for the making (at least if there is any deliberate lawmaking in the legal orders concerned) and for the adjudication of the law. This consists in the first place of a theory of interpretation of the law. To what extent do the adjudicators of the law have the freedom and/or the duty to interpret the law ? Which methods of interpretation may be used? Do they have any hierarchical relationship ? Which is the standard style of writing, e.g., for statutes or for judicial decisions ?

(d) A theory of argumentation. Which kind of arguments and of argumentation strategies are acceptable? Are these strictly legal elements, or social, economical, political, ideological, religious ones as well ?

(e) A theory of legitimation of the law. Why is law binding? What if it conflicts with some other, non-legal, social norms, such as religious norms? What kind of legitimation may give a binding force to the legal rules: a purely formal legitimation or (also) an

the question of the historical development of legal science and the question to what extent legal science has been faced with scientific revolutions . See, e.g.:

AARNIO, A., e.a., Paradigms, Change and Progress in Legal Dogmatics, Jyvaskyla, Gummerus, 1983; AARNIO, A., 'On the Paradigm Articulation in Legal Research' in: TAMMELO, I. \& AARNIO, A., Zum Fortschritt von Theorie und Technik in Recht und Ethik, Rechtstheorie Beiheft 3, Berlin, Duncker \& Humblot, 1981, p.45-56; WROBLEWSKI, J., 'Paradigm of Legal Dogmatics and the Legal Sciences', in: ZIEMBINSKI, Z. (ed.), Polish Contributions to the Theory and Philosophy of Law, Amsterdam, Rodopi, 1987, p.75-88; PECZENIK, A., The Basis of Legal Justification, Lund, 1983, p.129-134; ZULETA PUCEIRO, E., Paradigma dogmatico y ciencia del derecho, Madrid, 1981. FLODIN, M., 'The Possibility of Revolution in Legal Science', in: BANKOWSKI, Z. (ed.), Revolutions in Law and Legal Thought, Aberdeen, Aberdeen University Press, 1991, p.175-182; UUSITALO, J., Legal Dogmatics and the Concept of a Scientific Revolution, in: BANKOWSKI, Z., o.c., p.113-121; JORI, M., 'Paradigms of Legal Science', Rivista Internazionale di Filosofia del Diritto, 1990, p.230-254

Specifically on the historical development of science, from the point of view of pradigm, see: KRAWIETZ, W., 'Zum Paradigmenwechsel im juristischen Methodenstreit', in: KRAWIETZ, W., e.a., Argumentation und Hermeneutik in der Jurisprudenz, Rechtstheorie Beiheft 1, Berlin, Duncker \& Humblot, 1979, p.113-152; SIMMONDS, N.E., 'Law as a Rational Science', Archiv für Rechts- und Sozialphilosophie, 1980, p.535-555. See also: JAKOBS, H.H., Wissenschaft und Gesetzgebung im bürgerlichen Recht, Paderborn, Ferdinand Schöningh, 1983, 164 p. 
ideological legitimation (e.g. moral or religious values) ? What kind of legitimation gives the whole legal system its binding force? Is it sociological, historical, or axiological legitimation? And, in case of more than one kind of legitimation, in which combination, and under what conditions ?

(f) A common basic ideology: common basic values and a common basic world view. A common view on the role of law in society and on the, active or passive, role of lawyers. For western legal orders this includes, amongst others: a rationalist and individualist view on man and society (see above, chapter 2); a positivist view on law: law is generally considered to be valid, independently of its moral content (except in very exceptional cases, such as nazi-law, or abuse of rights); an instrumentalist view on law: law is not a spontaneously emerged social ordering, but a technique used by the ruling power to steer the society.

These various elements of the paradigm of legal orders will be helpful, both for comparing legal systems at the micro-level, because they offer the legal cultural framework in which such a research has to be located, and for comparing legal systems and legal families at the macro-level. A different conception of law (a) and a different world view (f) will already distinguish the legal orders belonging to different cultural families (see chapter 2). Within, e.g., the western cultural family, a different theory of legal sources (b) and of legal methodology (c) made until recently a clear distinction between Continental European law and Anglo-saxon law. During the decades of communist ruling in eastern Europe, it was possible to distinguish the 'socialist systems' from the other Continental European legal systems, because of differences, e.g., as regards the legitimation of the law (e), the world view (f), the role of law (f) and of lawyers (b) in society, and the theory of argumentation (d). Within one and the same legal system a distinction might be drawn between a different legal sub-culture, e.g., within the community of public law(yers), compared to the one of the community of private law(yers), because of differences in legal sources (b) and legal style (c). One example is the legal systems of Belgium and France: in both countries administrative law is hardly ever codified or even governed by statutes, and unwritten 'general principles of law' are more often used. The style used in decisions of the administrative courts (in both countries with the Conseil d'Etat as the supreme administrative court) is clearly different from the style used by private law courts (with the Cour de cassation as supreme court). The decisions of both Cours de cassation have much more in common with each other, as regards style, than they each have with the Conseil d'Etat in their own country. MARKESINIS has suggested a comparable difference in Germany: 
"For instance, the judgments of the German administrative courts are much richer in factual detail than the judgments of the Bundesgerichtshof though, if anything, the narrative is even drier! . ${ }^{54}$

All this says nothing about common or different history, or socio-economic conditions, about the content of the law, the legal principles, rules, concepts, or institutions. On one hand, it means that we have a tool for comparing legal systems, without having to take into account the concrete content of the law, nor the social and historical factors which are influencing and co-determining this content. On the other hand, it means that we still have a lot more potential elements at our disposal for comparing and distinguishing legal systems.

Legal systems may have different hierarchies of legal sources, different approaches to statutory interpretation, different styles of drafting judicial decisions, and differences in the legal technique and the legal concepts used, and yet still have basically the same methodology of legal reasoning and legal argumentation and even the same practical result. On the other hand, within one and the same legal system interpretations and reasonings followed by courts may diverge to such an extent as to reach completely opposite results.

A nice example is given by the field of obligations, in the case where the cohabitee stands as surety for the debts of the other cohabitee. This example shows how relative apparent paradigmatical identities and differences may be for the concrete outcome of a trial. It transpires that there are opposite views amongst the different German courts and amongst the different English courts, whereas several decisions of these courts offer a very similar reasoning and outcome, when compared to decisions in the other country. The problem the courts have had to face was that of the position of a cohabitee, generally the wife, of a debtor who had taken a loan from a bank, for which the cohabitee stood as surety. When the main debtor could not pay the debt, the bank made a claim to the cohabitee, who argued that she was not aware of what she signed, and/or that she was put under heavy pressure by her husband, so that the contract on the basis of which she stood as a surety was void.

54 MARKESINIS, B.S., 'A Matter of Style', 110 The Law Quarterly Review, 1994, 607-628, footnote 22 at p.610. 
At first sight this seems to be a relatively easy case, both under English and German law. As, from a pure doctrinal point of view, judges, in both legal systems, have argued that there was a valid contract, as the cohabitee being adult was presumed to know what she signed. Ius vigilantibus scriptum est (law is written for those who are vigilant)! This was the position taken by the 9th Zivilsenat (civil chamber) of the German Bundesgerichtshof in $1989^{55}$. The decision(s) of the Bundesgerichtshof was based on the principle of Privatautonomie, the autonomy of citizen to enter a contract, laid down in the German constitution (art.2, par.1 Grundgesetz) and the principle of the binding force of obligations, as laid down in the civil code( $\$ 241$ BGB). In England, in the case Barclays Bank plc. v. O Brien, the County Court took a similar position. The County court accepted that the wife had been misled by her husband, however, for this the bank could not be liable for that; thus the contract she entered into with the bank, was held to be valid. Dura lex, sed lex ! However, other judges considered this to be an unacceptable outcome and looked for ways to reach a more equitable decision. In Germany this was accomplished through a completely different interpretation of the Privatautonomie principle by the constitutional court, the Bundesverfassungsgericht, which annuled the decision of the Bundesgerichtshof of 16 March 1989. According to the constitutional court the Privatautonomie principle entails a duty on the courts to check the content of the contract, when it lays an unusually heavy burden on one of the contracting parties, and when it is the result of structurally unequal power positions. ${ }^{56}$ In other words, the Bundesverfassungsgericht emphasises a substantive autonomy, whereas the Bundesgerichtshof only took into account a formal autonomy.

In England, in the O Brien case, the Court of Appeal constructed a special equity theory, based on a 1902 decision (Turnbull v. Duval ${ }^{57}$ ). According to the Court of Appeal,

"if a wife signs a security document at her debtor husband's request the creditor will be unable to enforce the security unless either the debtor or the creditor has taken positive steps to try and ensure that the wife understands the import of the security documents or unless she has obtained independent advice" 58

55 In three decisions: 19 Jan. 1989 (BGHZ (Entscheidungen des Bundesgerichtshofs in Zivilsachen), vol.106, 1989; p.269); 28 Feb. 1989 (BGHZ, vol.107, 1990, p.92); 16 March 1989 (Zeitschrift für Wirtschaftsrecht, 1989, p.626). It is interesting to note that in all three cases the lowest courts, three different Landgerichte, decided in the same way as the Bundesgerichtshof but, the three courts of appeal (Oberlandesgerichte) decided in the opposite way BVerfG 19 Oct.1993, BVerfGE (Entscheidungen des Bundesverfassungsgerichts) vol.89, 1994, p.214236, at p.234. Turnbull \& Co v Duval, AC, 1902, 429, PC. 
According to the House of Lords, however, the case of Turnbull v. Duval could not be used as a precedent for the case under consideration. But it did not seem necessary to construct such a special equity theory, as the same result could be reached through the concept of 'undue influence' and the 'doctrine of notice'. The Law Lords argued that in a relationship based on confidence, such as between wife and husband, there is a presumed undue influence. This moves the burden of proof to the 'stronger party', who has to show evidence that there was no undue influence. The Bank was made liable on the basis of the doctrine of notice. The House of Lords considered it the duty of the creditor to inquire and to inform the cohabitee: the creditor has to take "reasonable steps to satisfy himself that the surety entered into the obligation freely and in knowledge of the true facts" and to "warn the surety (at a meeting not attended by the principal debtor) of the amount of her potential liability and of the risks involved and advise the surety to take independent legal advice"59. Again: this amounts to substantive autonomy and not just formal autonomy. While the wording is different to that used by the Bundesverfassungsgericht, the content in essence is the same. And, the difference in wording is primarily due to the different role of the Bundesverfassungsgericht as a constitutional court, on one hand, and of the House of Lords as a supreme court with much more power to decide the case in the most desirable way, on the other. What is also interesting to consider is that the difference in wording highlights how different courts use the legal concepts, rules, precedents, and the like, which are available within their legal system, in order to make the decision fit with it.

This example shows how similarities and differences at the level of (national) legal culture do not necessarily mean similarities or differences at the level of the actual legal regulation within a broader legal culture, such as the European one.

Firstly, differences and similarities as regards the primary rules of behaviour and as regards legal practice are influenced by, but not as such determined by differences and similarities as regards the secondary rules about the making and the adjudication of the law, and as regards legal culture.

Secondly, in cases such as these, a common ideology proves to be much more influential than other elements of legal culture and legal technique. What counts are the basic conceptions of equity and justice, as, for instance, the protection of the wife against abuse of power by her

decision of the House of Lords in: 4 All ER, 1993, pp.421j - 422b). 
husband and/or financial institutions. Once this moral choice has been made, legal technique is used in such a way as to reach the desired result. The divergent, and actually quite opposite, interpretations of the 'contracting autonomy' (Privatautonomie) of the parties in Germany show how legal technique is hardly an obstacle for reaching such a decision.

Yet, from this we have to conclude that, within the paradigm of legal culture different levels should be distinguished. A common ideology, common moral convictions form the deep level, which eventually comes to dominate the other levels. For instance, if need be, new sources of law, such as, in Continental Europe, 'unwritten general principles of law', might be accepted by courts in order to reach the (morally) desired legal outcome ${ }^{60}$. This, all the more, relativises the importance of the most apparent differences at the surface level: divergences in legal rules, legal concepts, and legal technique. Differences at this surface level and at the intermediate levels of the legal culture will almost certainly determine the way that the judicial decision is presented, but less so the outcome, as presumably there is, at the deep level, a common ideology. Thus the packaging will be different, but not the content.

A common ideology is also linked with the presence of similar economic and sociological conditions. There is more likely to be a similar view of man and society when the societal circumstances are comparable, as opposed when they are not. It is interesting to note how it was explicitly mentioned in both one of the German and one of the English court decisions that the case under consideration was one in a long list of similar cases brought before court over the last ten years ${ }^{61}$

We may conclude that point (f) (a common ideology) in the above given list of paradigmatical theories which are identifying a 'legal system', is the most important one, and

60 Examples of such, strongly morally laden, unwritten general principles of law, as accepted by courts in many European countries are: the good faith principle, or the prohibition of abuse of law (see: VAN HOECKE, M., 'The Use of Unwritten Legal Principles by Courts', Ratio Juris, 1995, pp.248-260).

"This appeal ... raises yet again a problem that has been before the Court of Appeal on a number of occasions over the past ten years or so." (Scott LJ in Barclays Bank plc v O Brien, 4 All ER, 1992, at p. 986)

"Since some ten years the civil courts have to deal more and more with cases in which young adults end up in a situation of high debts without perspective, because they have stand as a security for high bank loans for their partner or parents, although they had only a low income." (Seit etwa zehn Jahren werden die Zivilgerichte zunehmend mit Fällen befasst, in denen junge Erwachsene in ausweglose Überschul-dung geraten sind, weil sie für hohe Bankkredite ihrer Partner oder Eltern gebürgt hatten, obwohl sie nur über geringfügige Einkünfte verfügten) (Bundesverfassungsgericht 19 Oct.1993, BverfGE, vol.89, 1994, at p.215) 
partly determining the five other ones. A 'legal family' will be formed by legal systems which are basically sharing the same (or similar) conceptions on each of the six paradigmatical points. This will only be the case with societies with a comparable historical and socio-economic background. When being compared, Western and non-Western legal systems will show important differences at each of the six points, e.g. because a different relationship between law and other social norms, such as religious ones. But also within one and the same 'cultural family' differing clusters and distinctions could be drawn on the basis of those paradigmatical theories, such as a distinction between Latin-American legal systems and North American Common Law, or between the law of EU countries and some non EU European legal systems, or between EU Common Law legal systems and U.S. law, etc.. However, it is important to note that such distinctions and family ressemblances should not be limited to State legal systems, nor to legal systems as a whole. For instance, 'legal families' in administrative law or in criminal law may be rather different from those in economic law or family law. 


\section{What is law?}

If we want to compare 'legal systems' we need to look at the differing definitions of law which are offered to us by comparative law. Comparative law, until now has implicitly limited the concept of law to the legal systems of 'nation states'. This approach has rightly been criticised, mainly by legal sociolofgists and legal anthropologists, because it does not take into account different forms of 'unofficial' law. As an alternative a model of 'legal pluralism' is proposed. This pluralist model, however, is challenging the implicit concept of law, which is underlying most comparative research.

Most comparatists, like national doctrinal legal writers, arguably, do not appear to be overly concerned about a definition of law. To a certain extent they are right not to be too concerned. As evidenced by the numerous changing trends in legal theory, the subject is not an easy one and for a large part of their research they may easily work with some implicit, rather vague working definition. Moreover, an important starting point for any definition of law is the question what lawyers, in fact, call 'law' and what they do not.

However, if, e.g. in non-western cultures, we want to study the relationship between law, on one hand, and morals, religion and ideology, on the other, we need a definition of law, which allows us to clearly distinguish it from other social rules.

How is 'law' defined in legal theory?

Today, most legal theorists accept the distinction, made by Herbert HART, between 'primary rules' of behaviour and 'secondary rules'. Primary rules of behaviour are the rules imposing or allowing some kind of conduct under some circumstances. They form the bulk of the rules in any legal system. Secondary rules are rules about those primary rules: (a) rules of recognition, identifying rules as belonging to the legal system and defining their hierarchical position in it, (b) rules of change, empowering individuals (e.g. for contracts, or wills) or bodies to make new law, change or abolish the existing one, and (c) rules of adjudication, regulating the sanctioning of not following legal rules. ${ }^{62}$ In the Hartian concept of law, it is the union of these primary and secondary rules which creates a 'legal system'.

This ensures that we do not have to bother about other elements, as, e.g., efficiency, morality, the existence of some State power backing the legal system, etc... It does not follow that those characteristics may not be important in another context, we merely do not raise

62 HART,H.L.A., The Concept of Law, Oxford, Clarendon Press, 1961, pp.77-96. 
them in defining 'law'. However, if such a union of primary and secondary rules suffices as being a 'legal system', it follows, not only that legal systems which are considered to be immoral, such as Nazi-law, or legal systems which have a weak efficiency, such as international law, are 'really' law, but also that 'folk law' and various not State-linked organisations, such as churches or sports organisations may be considered to be a 'legal system' in their own right. It entails legal pluralism, also for comparative law.

HART, however, failed to consider another element, which should, in our opinion, be viewed to be essential for considering legal systems to be 'full legal systems': the development of a legal doctrine. This point will be developed in the next chapter.

Moreover, we are here only concerned with a formal definition of 'law'. In this case, however, the formal structure of legal rules, legal procedures and legal institutions are only one part of the story. As emphasised above, law is made daily and developed in legal practice, which in its turn is embedded in a legal culture. Comparative law is not a comparison of static, formal legal systems, it should take into account legal practice and legal culture.

But, as a tool for identifying and comparing legal systems the distinction between 'primary' and 'secondary' rules is another useful element, besides the distinction between the rationalist and irrationalist approach and between the individualist and collectivist approach, which are distinguishing a 'Western' legal culture from non-Western legal cultures, and besides the analysis of paradigmatical theories, which make it possible to identify 'legal families' within a broader 'legal cultural family'.

A comparison at the level of secondary rules offers a picture of the formal structure of the law, whereas at the level of the 'primary rules' it is the rules of behaviour, the legal rules in the narrow sense, which are compared.

Legal systems with differing rules of behaviour may well share similar formal rules, for instance as related to the way legal rules are created, changed and abolished.

Legal systems sharing similar or even identical primary rules of behaviour may show important differences at the level of the secondary rules, e.g., because of different procedural rules or rules of evidence, which may entail important divergences in legal practice. 


\section{The Importance of Legal doctrine}

In the introduction we argued that the work of comparatists is basically comparable to the work of doctrinal legal writers. In order to be able to make comparisons, all research in comparative law has to start with the reconstruction of the legal landscape under consideration. A better insight into the doctrinal activity would thus be useful for comparatists.

However, legal doctrine is not only important for comparison with comparative law as a discipline, it is at least as important as a part of the research object of comparative law. Comparatists know that it is impossible to limit oneself to statutory rules when comparing the law of two legal systems. This already proves impossible when one of the compared legal orders does not have statutory rules in the area under consideration, but only customary law or case law. Yet even as regards codified legal systems it is now generally accepted that the meaning and the scope of statutory rules may considerably change through the interpretation by judges when adjudicating the law. Having a correct view about legal regulation in some legal order means knowing its statutory rules, its court decisions, and, in some cases, its customary rules, and, as is becoming apparent, a capacity to appreciate the important differences which stem from legal culture. Actually, court decisions are the only legal source all legal orders have in common. However, as we have noted in the previous chapter a full legal system contains more than statutory law (and/or customary law) and case law. It also encompasses a legal doctrine. Legal doctrine forms an essential part of any full legal system. It allows the development of the conceptual framework of the legal order and its legal methodology. Except for maybe a short time after an all encompassing codification, as with the Code Napoléon, legal doctrine is needed for structuring case law, statutory law, customary law. Individual cases should fit into the whole legal system. Isolated statutes should fit with the other ones. Customary rules have to be interpreted in such a way that they reach a minimum level of coherence. Structuring legal sources means interpreting them in such a way that they form together a coherent whole.

Modern legal doctrine often hides its creative work behind a fiction, such as the 'rational legislator', who is presumed to use words that have always the same meaning, unless explicitly mentioned otherwise, who is presumed not to have wanted contradictory, or even incoherent legislation, nor absurd or clearly unjust results, etc.. The picture of the actual legislators is, of course, less positive. This means that legal doctrine is not just describing and reconstructing some legal reality, but rather it is also to a certain extent playing a part in the 
continual construction of the legal system itself, as well as portraying a certain type of legal culture, continuing a legal tradition. In the English common law it is rather the 'fiction' of historical continuity which acts as a structuring element. As Otto KAHN-FREUND has noted:

"Every decision appears in the cloak of a mere application or adaptation of pre-existing principles laid down in earlier judicial pronouncements. Where historical continuity and systematic consistency are in conflict, it is the former which prevails, and it prevails even where the question at stake is the interpretation of a statute. ${ }^{63}$

The importance of legal doctrine explains why, for example, international law is considered to be 'really' law, whereas the rules of an international sports association generally are not considered to be fully 'law', although otherwise both legal orders have very similar characteristics: they both have primary rules of behaviour and secondary rules for the making and the adjudication of the law. They are internationally recognised as an autonomous (legal) order in their own right. In both cases customary rules may play an important role, and enforcement of judicial decisions may prove to be more difficult than in State legal systems. But international law has its own legal doctrine and conceptual framework, which sports organisations, as with most non State legal systems, do not.

\subsection{The task of legal doctrine}

As it appears from the analysis above, the work of legal doctrine is essentially describing and systematising the law.

\subsubsection{Describing the law}

Describing the law entails more than just reporting the legal rules, and certainly more than simply quoting the wording of legislative texts. In the first place one has to determine which legal rules are in force at the time of consideration. This is a formal problem: has a specific rule been repealed or not? Are there additional bye-laws? However, it is also a problem of content: is the rule under consideration compatible with a rule of a higher level in the hierarchy of legal sources ? If not, than the rule will be considered to be invalid, and thus non-existent in that legal order. But concluding that this rule is invalid is not simply a descriptive statement, it is the conclusion of an interpretation. Some may interpret the rules

63 KAHN-FREUND, O., 'Introduction' in: RENNER, K., The Institutions of Private Law and their Social Functions, London, Routledge and Kegan Paul,, 1949, p.10. 
under consideration in another way, so that there is no incompatibility, and thus, no invalidity.

This shows to what extent description and interpretation of the law are interrelated. Every description of the law implies, inescapably, an interpretation of the law. This is often an unconscious interpretation, usually a (rather) generally used interpretation, and, exceptionally, a new, original interpretation. But, it is always an interpretation.

Moreover, facts do not simply exist. They are always seen, described, classified through the eyes of the legal system. No description of facts which would be independent from the legal system is possible. It is the conceptual framework of the legal system which guides any description of reality . Reality is ordered, and to a certain extent constructed on the basis of this conceptual framework. One 'sees' some other reality when the legal concepts used make a basic distinction, for instance, between 'rats' and 'non-rats ${ }^{64}$, compared to a legal system which distinguishes basically between 'movables' and 'non-movable things'. Using concepts like 'trust' or 'abuse of law' can order reality in a different way from that of legal systems which do not use such broad concepts. When, e.g., a politician receives money from a private company to finance his election campaign, this might be considered to be 'corruption' today, while it was a normal way of financing yesterday, and it still is in some other legal systems. Because reality is structured in a different way, some solutions for problems appear to be possible in one legal system and not, or at least very difficult, in another legal system. Legal concepts, structures and institutions, or indeed the whole of the legal technique offered by a legal system is on one hand offering opportunities for solving problems, but on the other blocking different solutions. Both within and outside law some conceptual framework is necessary to grasp reality. Such a conceptual framework reduces the enormous complexity of reality and is necessary to make a normal life possible. On the other hand, it limits the opportunities to see things in a different way, to handle problems and to solve them. The price we pay for our freedom and our opportunities is the deliberate limitation of this freedom and these opportunities. This conceptual framework, both inside and outside the law, is only to some extent a rational construction, based on pure rational choices. Every culture, every legal system contains some historical coincidences, which make this culture or legal system somewhat less rational and/or somewhat less coherent. The English legal system is here one of the best examples of it, because of its strong, direct roots in history.

64 As, e.g., the Kapauku tribe in Papua did, as recorded by Leopold Pospisil (POSPISIL, L., Anthropology of Law. A Comparative Theory, New-York, Harper \& Row, 1971, p.274-302, with a scheme at page 295). 
All this means that any 'legal' description of facts is determined by the legal rules of some legal system and by its conceptual framework, as worked out and systematised in legal doctrine over the years. The importance of legal doctrine, as a discipline is sometimes hidden, for instance, because the work is done, not by professional academics, but by judges and other practitioners, as has been the case in the history of English law, a characteristic which arguably has held true until recently ${ }^{65}$. Also, as in the case of all major codifications over the last few centuries, doctrinal concepts have been taken over by the courts or by the legislator. Yet, it is not because the work of legal doctrine has been recognised and accepted in a formal way by judges and legislators that it has become less important. On the contrary, it tends to prove the importance of the doctrinal work for the development of legal systems. The fact that the conceptual framework became, to a large extent, part of the positive law, through legislation and/or court decisions, does not diminish its importance for the description of reality, but in fact strengthens it.

\subsubsection{Systematising the law}

In modern legal systems, legal doctrine often is confronted with rapid changes in the law, an inflation of legislation, and fragmented, often hap-hazard changes of legal institutions or branches of the law. Moreover, the exact content of legislative rules, or of other legal sources, is, eventually, determined by the body which has the last word as regards the interpretation of the law. These are the courts, and in this case especially the supreme court, and/or the constitutional court within the legal system. The patchwork of both legislation and case law force legal doctrine to (re)systematize the law. Such a systematisation is carried out by a (re)interpretation of the differing legal rules, in the light of a coherent unity, on the basis of a number of basic concepts and principles. This indicates that there is a close link, not only between interpretation and description, but also between interpretation (of an isolated rule) and systematisation (of a set of rules). Legal doctrine is not just imposing its conceptual framework on the law, from the outside. It has to work with the concepts and words as used by the legislators and the courts. This is considered as one of the main obstacles to accurate

65 The House of Lords case of White $v$ Jones $(2$ WLR 1995, 187) provides evidence of the increasing tendency of certain judges to refer to Academic doctrine (see, esp., Lord GOFF at pp.202-203). This is in marked contrast to the traditional position, no doubt still shared by some English judges where "It is to my mind much to be regretted, and it is a regret which I believe that every judge on the bench shares, that text books are more and more quoted in court." (KEKEWICH, J., in Union Bank $v$ Münster, 37Law Reports. Chancery Division 1887, p.51, at p.54). 
comparative research, namely the impossibility of adopting a completely external point of view. The conceptual reconstruction of the legal materials of a legal order is always partially determined by the concepts and wordings used in those legal sources. Until now the few or limited attempts of comparative law have been unsuccesful in developing some conceptual meta-language which would allow for an external comparison. Alongside those problems of understanding and judging differences in legal culture, the development of some conceptual legal meta-language, which could cover at least two or more different legal orders, will be a necessary condition for a real development of comparative law.

On the other hand, as we have already mentioned above, legal doctrine can sometimes succeed in gaining the acceptance by legislators or courts of newly developed concepts. This means that comparative law could, in the long term, succeed in influencing the individual legal systems by making (part of) its meta-language accepted by some of these legal orders. Such a new conceptual framework of comparative law thus could filter through into the national legal systems. In this case, the scientific, doctrinal meta-language would become the ordinary, legal language. To some extent this is what happened with the conceptual framework of learned Roman law when laid down in the great Continental European codifications, such as the French Code civil and the German Bürgerliches Gesetzbuch, in Nineteenth century. These codes had been prepared scientifically over a period of many centuries. However, today one could hardly expect comparative law to reach similar results in just a few years or a few decades. It is a long term project, for which many 'glossators' and 'post-glossators' will be needed, before any new 'codificators' would succeed in making an appropriate synthesis. ${ }^{66}$

66 Walter VAN GERVEN puts forward his vision of such a long term approach: making use of multinational casebooks as one important element in the creation of a common law of Europe. See generally: 'The Case Law of the European Court of Justice and National Courts as a Contribution to the Europeanisation of Private Law', 3 European Review of Private Law 1995, pp.367-378. 
However, this development has already started. Lawyers are being increasingly confronted with a plurality of legal systems applicable over one and the same territory. With both a federalist decentralisation of legislative power in many European Union countries and the delegation by all member-State of the European Union of certain significant legislative and judicial power to the European institutions, none of these legal orders has, today, in its territory, full legal and political power, as was traditionally set out in the concept of sovereignty ${ }^{67}$. There is no strict hierarchical relationship between those legal orders as such, only between specific rules within those legal systems. They remain independent from each other, but closely interrelated. In EU member-States, national commercial law is to a large extent European law. ${ }^{68}$ Some decisions of the European Court of Human Rights have dramatically changed the law, not only in the condemned State, but in several other European countries as well. An example is the Marckx decision, by which Belgium was condemned for the discrimination, in inheritance law, against children born outside a legal marriage. ${ }^{69}$. This decision has thoroughly changed family and inheritance law, both in Belgium and beyond. ${ }^{70}$

All this shows that the description and the systematizing of law within (national) legal doctrine is inescapably becoming a cross-border activity. As an example of the influence of European Union law on English legal doctrine, John BELL describes the effect of the Marshall and Foster cases ${ }^{71}$ on the conceptual framework of English law. Through European law in this area the French concept of 'public service' has now been introduced into English law. ${ }^{72}$. In order to describe English law now, as regards the question whether the

67 Jean Bodin defined 'souveraineté' as "la puissance absolue et perpétuelle d une République" (the absolute and eternal power of a republic) (BODIN, J., De la République, Paris, 1583, book I, ch.VIII, p.122).

E.g.: see Art.85 and 86 of the Treary of the European Community, and the following Council Directives:

Council Directive 93/13/EEC on Unfair Terms in Consumer Contracts (OJ L 95/29); Council Directive 94/47/EEC on Right to Use Immovable Property on a Timeshare Basis (OJ L 280); Council Directive 90/314/EEC on Package Travel, Package Holidays, and Package Tours (OJ L 158/59). European Court of Human Rights, 13 June 1979.

Other examples of important decisions of the European Court of Human Rights in the field of family law, all to be found in the Recueil des Arrêts et Décisions de la Cour européenne des droits de l'homme, Séries A, are: Johnston v Ireland, $\mathrm{n}^{\circ} 112$ (divorce); F. v Switzerland, $\mathrm{n}^{\circ} 128$ (right to remarry); Olsson $v$ Sweden, $\mathrm{n}^{\circ} 130$ (family separation); Eriksson $v$ Sweden, $\mathrm{n}^{\circ} 156$ (placement in a guest family and right to visit) 3 All ER, 1990, 897. 
classification of public bodies such as health authorities or nationalised industries as organs of the state, it is, henceforth, necessary to include decisions of the European Court of Justice, and, in order to properly understand this area of English law, it will be necessary to include French legal discourse. Here, we are clearly faced with comparative law as an instrument of integration.

As we have already mentioned, the mixture of cultures on our territories, today, entails a confrontation of fundamentally different legal cultures with each other, in a more intensive manner than ever done before. Private international law becomes more important and the phenomenon leads to new problems of systematisation: e.g., how is the 'endowning' of a wife by her husband in Morocco to be interpreted and incorporated in the conceptual framework of marriage and divorce law in a European country $?^{73}$

Lastly, the doctrinal systematisation of the law also means adapting the law to external, societal changes. On a daily basis as a judge, as an advocate, as a company lawyer, or as a civil officer, lawyers are adapting the law to social reality and societal needs. This is the difference between 'law in the books' and 'law in action'. This interaction between the written law and, constantly changing, social reality leads to continuous reinterpretations, and, in the long term, resystematisations, of the law. In codified legal systems such doctrinal and judicial reinterpretations are regularly confirmed by legislative changes, whereas the opposite, i.e. a legislative reaction against legal practices, which seem to be 'contra legem', or at least at variance with the wording of the statutes, rarely occurs.

Reinterpretation and resystematisation, with a view to adaptating the law to the social reality may take place at different levels. At one such level legal practice may show a gap or a contradiction in the law. These can be filled by broadening the scope of some neighbouring rules, or by wording some (unwritten) general legal principle, contradictions between rules may be solved by limiting their scope. Secondly, technological innovations regularly make the current legal rules inadequate and outdated. For example, it would seem desirable to prevent people from breaking into a computer data base and 'stealing' secret information. Yet is such an activity covered by the criminal rules on 'theft' or 'breaking in'? Thirdly, the interpretation and the systematisation of the law may be influenced by new social problems

pp.182-184; BELL, J., 'English Law and French Law - Not So Different ?', Current Legal Problems, 1995, pp.73-74. répudiation', Revue du droit des étrangers, 1990, pp.176-183 
(e.g., the use of drugs, or traffic problems) to which, partly, old, inadapted legislation has to, or at least could, be applied. At last, the law, sometimes, is adapted to changed views in society.

\subsection{The Methodology of Legal Doctrine}

Describing the law is, we have said, inextricably bound up with interpretation. When describing the law, the doctrinal legal writer is constantly, either implicitly or explicitly, formulating hypotheses as regards the meaning of legal concepts, legal rules, legal principles or legal institutions. ${ }^{74}$ These hypotheses are checked on the basis of materials which generally are considered to be authoritative (e.g.: established precedents, supreme court decisions, legislative materials) and by using the classical interpretation methods. Accepting an interpretation, eventually, is not based on some 'objective' certainty, but on an inter-subjective consensus within the legal community.

However, the interpretation of (relatively isolated) rules and concepts is also influenced by the systematicity of a larger whole (a legal institution, a branch of the law or even the whole legal system). The English legal system is traditionally considered to be a case-based system, moving from one factual situation to another, by use of such methods as analogy, and being less systematised than for example the French or German code-based systems. However, even in a relatively less systematized legal system, such as the English one, certain key cases demonstrate judicial awareness of the systemic consequences of a certain line of interpretation. If we were to take the general principle of legal certainty and apply it to certain areas of the English legal system, then we may get some idea of how legal interpretation by English judges is indeed influenced by certain systematic considerations. One such 'systematic' consideration that we may posit as an example is the threat of opening the 'floodgates' to a vast and uncertain extent, with respect to tortious liability ${ }^{75}$. This is an argument which is often used by English judges when refusing a claim in tort cases such as those relating to economic loss. Leading English cases such as Spartan Steel and Alloys Ltd

74 See AARNIO, A., Philosophical Perspectives in Jurisprudence, Helsinki, 1983, p 163-184; see also: AARNIO, A., Denkweisen der Rechtswissenschaft, Vienna/New-York, Springer, 1979, p.49-50, where he is defining legal doctrine as 'the science of meanings'. 218. 
$v$ Martin \& Co Ltd ${ }^{76}$ and Murphy $v$ Brentwood District Council ${ }^{77}$ may arguably be cited as examples where a choice had to be made as to whether to allow a claim for 'pure economic loss'. A decision in favour of doing so could have as its consequence the opening of the floodgates to an immeasurable number of claims which could 'flood' the English legal system. Refusing compensation for pure economic loss, on the other hand, would ensure that the legal system functions as before, and that the 'floodgates' are kept firmly shut ${ }^{78}$. Such metaphorical devices are often invoked in the English legal system ${ }^{79}$, certainly most predominantly where the jurisdiction of Equity plays a role. In certain situations arising in the English law of tort the threat of 'opening the floodgates' is often posited as a strong judicial argument for refusing compensation. What is interesting to consider here is to what extent the general legal principle of 'legal certainty' plays a role in shaping important areas of the 'weakly systematised' English legal system, and such concerns to protect the functioning of the systematic whole may be detected by looking closely at frequently used legal arguments such as the threat of opening the 'floodgates'.

Interpretation and systematisation thus are closely interwoven. The conception of the systematicity of the law functions as the theoretical framework, on the basis of which some legal interpretations are possible and other ones are not. Where interpretation means hypothesis about the meaning of a rule, systematisation offers a theory for wording interpretational hypotheses ${ }^{80}$.

\footnotetext{
$76 \quad 3$ WLR, 1972, p.502.

$77 \quad 1 A C, 1991$, p.398.

78 "If claims for economic loss were permitted for this particular hazard, there would be no end of claims. Some might be genuine, but many might be inflated or even false." (Lord DENNING in Spartan Steel \& Alloys Ltd v Martin \& Co (Contractors) Ltd, 1 QB 1973, p.27).

But not only in the English legal system. The same argument plays a similar role in the area of pure economic loss in the Netherlands (see KOTTENHAGEN, R.J.P., 'Buiten-contractuele aansprakelijkheid voor economische schade. Een rechtsvergelijkende studie naar aanleiding van recente ontwikkelingen in het Engelse (bouw-)recht omtrent de mogelijkheden tot vergoeding van economic loss claims', Bouwrecht 1991, pp.339-360), and in Austria (see POSCH, W., 'Der ungeschützte Strombezieher als Fall des mittelbaren Schadens in der Rechtsprechung des OGH', Juristische Blätter 1973, pp.564-568; decision of the Oberste Gerichtshof, ZVR 1979, p.93), but not at all in Belgium, France or Germany. Again the difference is not between Common Law and Civil Law, but appears to follow unexpected geographical lines.
}

Aulis Aarnio defines a legal doctrinal theory as "a set of concepts and propositions which systematize legal norms in a certain way." (AARNIO, A., Philosophical Perspectives in Jurisprudence, Helsinki, 1983, p.216). 


\subsection{Legal doctrine and comparative law}

Legal doctrine is the description and the systematisation of the law in one specific legal system. Comparative law is comparing such legal systems. Together with statutory law, case law and customary law, legal doctrine is an object of the comparative study. However, it is also its scientific model. Comparative law is also concerned with the description and the systemation of law, but this is from an external point of view. Taking an external position towards one's own legal system is problematic, both from a practical and an epistemological point of view. Nevertheless, the ambition of comparative law has always been to develop some neutral framework, some common language with which several legal systems could be described in a way accessible and completely understandable by lawyers belonging to anyone of those legal systems. We are not discussing here the problems it entails ${ }^{81}$. We merely wish to emphasise that some (relatively) neutral, objective, accessible description is a key ambition of comparative law.

However, a really common language, a common conceptual framework has still to be developed. At this point, we want to emphasise only that this new conceptual framework is to be developed at the level of systematisation, one of the two tasks of legal doctrine, and, obviously, also of comparative law.

Because legal doctrine is an important element of developed legal systems, the stage of development of legal doctrine in the different legal systems seems to be an essential stage of enquiry for comparative law.

International football associations, for example, have no legal doctrine of their own, and are, for this reason, not fully developed legal systems They borrow legal concepts, legal procedures, etc., from one or more State legal systems. Their study might be useful for comparative law, but not at the first stage. At the most they are interesting as a kind of hybrid legal system, but, unlike State legal systems, they do not offer new concepts or principles.

International public law, on the other hand, might demonstrate deficiencies as regards its effectiveness - and obviously much more than it is the case with international sports associations - but it has a developed legal doctrine. For this reason, as we already noted above, it is a more developed legal system, when compared to the legal systems of, e.g.,

81 See, on the problem of a common language in comparative law: VAN HOECKE, M., 'Hohfeld and Comparative Law', International Journal for the Semiotics of Law, 1996, pp.185-201, esp. at pp.188201. 
sports associations, and more interesting from the point of view of comparative law.

The Common Law, when compared to Continental legal systems, offers a perceivably less developed legal doctrine. The prevailing tradition draws upon case to case reasoning, with a notable reluctance towards systematisation and general principles. Common lawyers have remained at the stage of induction, whereas the civil law systems combine both induction and deduction. In this sense, current English law is closer to Roman law than to current civil law. As SAMUEL has noted:

"If the history of science is one of a tension between the concrete and the abstract as Blanché claims, and that induction and deduction mark the two steps in the development of scientific thinking, then the reason why there appears to be an inner relationship between Classical Roman and English law is that the two remain in the same scientific stage of development. Roman Classical law and modern common law are both inductive in their method. " 82

This difference in doctrinal development can explain why some legal systems have been much more influential than other ones: e.g.: Roman law during Middle-Ages, the French Code civil during 19th and 20th century, the German Bürgerliches Gesetzbuch during 20th century, and probably the Dutch civil code during the 21 st century. Because of its arguably less developed legal doctrine, the common law may not be expected to play an important role in the future development of a common private law in Europe, as it never has been overtly influential in the past either. As Hugh COLLINS has noted:

“...the English law of contract embraced many transplants from Roman Law and Civil Law systems during the nineteenth century. But the traffic was a one way voyage, for French and German laws of contract betray no signs of influence by the Common Law." ${ }^{\text {. } 33}$

This influence has nothing to do with political power, nor with the intrinsic qualities of the concrete rules and legal solutions the common law offers, nor with differences amongst legal cultures. It is primarily linked with the development of legal doctrine. This means that more elaborated concepts and institutions, such as the trust, might well prove to be attractive to other legal systems. However, for the time being, such highly developed legal concepts and legal institutions are largely lacking in the common law, due to its relatively low level of doctrinal systematisation.

82 SAMUEL, G., The Foundations of Legal Reasoning, Antwerp, Maklu, 1994, p.84, with reference to BLANCHE, R., L épistémologie, Paris, Presses Universitaires de France, 3rd ed., 1983, pp.64-65. Studies 1991, 396-406, at p.397. See, for some other examples of foreign influences on English law: BINGHAM, T.H.,'There is a World Elsewhere : The Changing Perspectives of English Law', 41 International and Comparative Law Quarterly 1992, 513-529, at pp. 522-528. 
At last, legal doctrine is important for comparative law, because it is a privileged forum where paradigmatical theories, as, for instance, a theory of legal sources, are made explicit and where proposed new (paradigmatical) theories are being discussed.

\section{Towards a New Model for Distinguishing 'Legal Families' in the World}

It should now be generally accepted that the context of law is an essential part of comparative research. This context is not only the material context of sociology, history, economy, but also the ideological context of the law and what could be called the juridical way of life'(i.e. all elements not belonging to ideology in the strict sense, but rather to tradition, or to fashion). Different concepts have been used for indicating this immaterial context, such as 'legal style', 'tradition', 'mentalité'. We prefer to use the concept of 'law as culture' as a way of accomodating the two other tenets of comparative law: 'law as rules' and law as an instrument of integration.

Within a 'law as culture' approach three levels may be distinguished.

At a first level, legal systems have to be located in the context of the large cultural families at a world scale: African, Asian, Islamic and Western (legal) cultures. There appear to be fundamental differences amongst these cultures as regards the role of law in society and the attitudes of people towards law, which may be analysed on the basis of the oppositions rationalism - irrationalism and individualism - collectivism. Those differences are so basic that a comparison of legal systems belonging to different cultural families is of an essentially different nature, when compared to comparative research within one of those large cultural families. Comparisons at this 'intercultural' level are different. Comparison here does not make much sense at a technical level, it should rather take place from an anthropological or sociological perspective, which means a societal comparison of the actual role and functioning of law in the compared societies, rather than comparing statutory rules or court decisions.

At a second level, comparative law in the more traditional, strict sense is possible within each of the large cultural families. This comparison should start from the basic elements which form the hard core, the paradigm of every legal system. These paradigmatical elements can be structured around six areas: the conception of law, the theory of valid legal sources, the methodology of law, the theory of argumentation, the theory of legitimation of the law, the generally accepted basic ideological values and principles.

At a third level a more or less purely technical comparison is possible when comparing 
legal systems having the same paradigmatical theories in each of those six areas, as is the case with the continental Member States of the European Union. Here, concrete comparison of statutory and judicial rules of behaviour can be fruitful, because the context, the legal culture is very similar, so that often only minor sociological, historical, economic or ideological elements have to be taken into account, whereas also the conceptual framework and legal language are to a large extent the same.

At each of these three levels comparative law may be employed in a more involved, active way by using it as an 'instrument of integration'.

This is the case in non-Western legal cultures where Western law has been imported and to a certain extent integrated into the domestic legal system and legal culture.

But the currently most fascinating place where comparative law is being used as an instrument of integration is the European Union. One should not deny the influence of the emergence of the supranational, as a key development that comparatists must come to terms with, as such modern legal structures are a driving force leading to such noticable 'intersystematicity'. This means a constant interaction between legal doctrine of two or more legal systems, mutually influencing each other. This is currently the case in the supranational structure that is the European Union, and most notably in the European courts and with regard to European directives. Of course, some unilateral influence by one legal system on another, is not new at all, but rather a constant element in legal history over all time. New in this European development is that lawyers are forced to take this 'intersystemic' approach. Within European jurisdictions judges from all Member States have to develop some common legal language. They are constantly confronted with differing reasonings and conceptual frameworks, which they have, to a certain extent, to integrate into their own legal language. A new, common European legal language is slowly developing. 
Another forced 'intersystemic' approach is to be found in the effect of European directives on national legal doctrines. Through European directives new values and principles are being introduced into the national legal systems and disturbing the coherence of some or all of their legal doctrines. Traditional divisions, such as those between vendor and buyer, landlord and tenant, are being partly replaced by new divisions, such as those of 'consumer' and 'professional supplier of services'. General principles, which already belonged to some legal systems in the European Union, such as the good faith principle ${ }^{84}$, are, via EU law, being introduced into other legal systems, such as the English one, where they do not fit with the national legal tradition ${ }^{85}$. As a result foreign legal concepts and principles have to be 'translated' so as to fit with the national legal doctrine. When integrating those concepts and principles into their own doctrinal system some changes in the own conceptual framework cannot be avoided.

Here, comparative law being an instrument of integration clearly mixes up with the development of State legal systems. Comparative reasearch and national doctrinal analysis become closely intertwined.

When comparing legal systems within the 'law as culture' approach, it appears that shared ideological viewpoints, both at the second (intra-cultural) and the third level (intra-familial), play an essential role and may influence largely the other paradigmatical elements. In the long term they may change some paradigmatical theories (e.g. by accepting 'unwritten general legal principles' as a new source of law), while in the short term they may influence the way they are interpreted and applied in practice (e.g. a more active role for the judge, or more emphasis on teleological interpretation rather than a literal construction of statutes). Common basic ideology thus forms a kind of deep level within a legal culture, whereas the other paradigmatical theories form the intermediate level. The concrete rules within the legal system are then to be located at the surface level: it is the rules of behaviour, the legal concepts, and the secondary rules of change and adjudication of the law as far as they are not included in the paradigmatical hard core of a legal system. These elements of legal technique at the surface level do not actually play an important role in determining differences and similarities between the solutions a court might give to a case. But they will, of course, strongly influence the wording of the decision and the justification given to the legal solution.

\footnotetext{
$84 \quad$ See Council Directive 93/13/EEC, Art.3 (1). 229-254.
} 
Differences in legal culture, and in conceptual frameworks entail fundamental problems for the establishment of a common legal language for comparative law. On one hand, such a common language is needed if comparative law aims at becoming a genuine and international discipline, and not a strand of private international law, in which every legal system has its own private international law system, and only a very limited internationally common language. It is needed if one wants to avoid a sheer juxtaposition of legal languages and legal systems.

On the other hand, language is such an essential part of culture, that it seems very difficult to perfectly understand and master a foreign legal language. As it is, to a certain extent, language which creates reality, a different legal language produces another kind of 'legal reality'. In this sense the 'functional approach', as advocated by ZWEIGERT and KÖTZ, suggests something which is not possible: a legally neutral approach to reality. There is no 'legal reality' outside law. In order to grasp this legal reality one has to learn the legal language of the foreign legal system, or to develop some new common legal language. This, however, cannot but change reality, as is shown by the introduction of the western concept of human rights in almost all non-western countries, or from the developments within the European Union, where there is some dialectical interaction between national legal systems and European law.

A common legal language can be built in two ways: an internationally common scientific meta-language (transdisciplinarity), which uses existing common concepts and elements and/or develops new ones; or a constant exchange of concepts and viewpoints between legal systems (interdisciplinarity), as it is already to some extent the case amongst legal systems within the European Union.

The traditional distinction of three 'legal families': the 'Romano-Germanic family', 'the Common Law family' and the 'Socialist family' did not take into account the fundamental differences amongst the four large cultural families in the world. For example, it arguably divided African legal systems according to their colonial history, through which they became part of the family of the colonising state, and not by virtue of their, much older and much more influential, own cultural history. Moreover, this traditional distinction was confusing two different criteria: legal technique and conceptual framework on one hand, and ideology on the other. At the level of legal technique there remains, today, only the distinction (within the Western legal culture) between Romano-Germanic and Common Law families, although there appears to remain no more paradigmatical differences between both 'families' as far as the EU legal systems are concerned. At the level of ideology, within Western legal culture, 
there seem to be no differences which are, nowadays, structurally dividing or linking some of its legal systems. Within Europe, the main ideological opposition, between 'socialist' and 'capitalist' legal systems, disappeared.

All this highlights the point that comparative law is in need of a new model for structuring groups or 'families' of legal systems. What has been developed in this article could serve as a starting point for such a new model.

In general, comparative research needs to be under-taken with the three outlined concepts of law in mind: 'law as culture', 'law as rules' and 'law as an integrative instrument'.

We repeat that when distinguishing differing 'legal cultures' or 'legal families' a first division should be made in four large cultural families, African, Asian, Islamic and Western. A second division within each of these cultural families could be made on the basis of paradigmatical similarities and differences. These paradigmatical elements can be divided into six areas, of which the common ideological viewpoints form the deep level, and the five other ones an intermediate level (conception of law, theory of legal sources, methodology of law, theory of argumenta-tion and theory of legitimation of the law). If there is a common paradigm in each of those six areas, a further division is possible at the surface level of concrete rules and concepts. Within the second and third division the distinction can also be used between primary rules of behaviour on one hand, and the secondary rules of change and adjudication of the law, on the other, as a tool for comparing legal systems.

At last, one could distinguish between legal concepts, rules and institutions as 'rational choices', on the one hand, and as 'coincidences', on the other. Especially when using comparative law as an instrument of integration, this distinction may be helpful to choose between two differing legal concepts, rules or institutions.

Here, obviously, an interdisciplinary approach will be needed. Especially useful in this matter could be legal history (for understanding how such legal elements came to birth or evolved accidentally or rationally) and economic analysis of law (for making a rational choice amongst differing concepts, rules or institutions).

But also more generally comparative law is, by definition, an interdisciplinary endeavour. In a 'law as culture' approach anthropology and sociology of law are always present, be it directly or in the background. Depending on the chosen topic and approach all other 'metajuridical' disciplines may come into play.

Eventually, every attempt to distinguish 'legal cultures' or 'legal families' is to a certain 
extent arbitrary and will depend on the field of law chosen and on the characteristics considered to be important by the comparative researcher. For this reason it seems important to take into account the cultural identity as perceived by the people and the lawyers belonging to some community ${ }^{86}$ and which, of course, presupposes some basic common ideology. It is, to some extent, the fact that people identify their community as being different from another one which 'creates' the community and 'creates' the difference with the outside world.

86 This is what the Japanese sociologist of law and comparatist Mesaji CHIBA has called the 'identity postulate' of a legal culture (CHIBA, M., 'The Identity Postulate of a Legal Culture' in Archiv für Rechts- und Sozialphilosophie, Beiheft Nr.30, 1988). 